\title{
Los puentes en Angostura, Turrialba
}

\author{
Dr. Luko Hilje ${ }^{1}$, Centro Agronómico Tropical de Investigación y \\ Enseñanza, Costa Rica \\ Fecha de recibido: \\ 21 de marzo, 2017. \\ Fecha de aceptación: 24 de octubre, 2017
}

\section{Resumen}

En Costa Rica, uno de los anhelos de varios gobernantes y en particular de Braulio Carrillo, fue construir un buen camino entre el Valle Central y la costa del Caribe, para favorecer tanto la exportación como la importación de bienes y mercaderías. El camino a Matina, que databa de la época colonial, era inadecuado y, además, obligaba a cruzar el río Reventazón en un paraje inseguro, en las cercanías del actual Siquirres. Por tanto, en el gobierno de Juan Rafael Mora se decidió desechar esa ruta y buscar un mejor sitio para atravesar el río, y fue cuando se localizó Angostura, en Turrialba. En este artículo se documenta de manera detallada, con base en expedientes disponibles en el Archivo Nacional y periódicos existentes en la Biblioteca Nacional, cómo fue que ese punto fue descubierto, así como las iniciativas y las personas que hicieron posible la construcción de los cuatro puentes erigidos ahí a lo largo de 110 años: uno de troncos y calicanto, uno de madera y techado, uno de hierro y el actual puente de acero, levantados durante los gobiernos de Mora (1852), Jesús Jiménez Zamora (1865), Julio Acosta García (1923) y Mario Echandi Jiménez (1962).

\section{Abstract}

\section{The bridges of Angostura, Turrialba}

In Costa Rica, several rulers and in particular Braulio Carrillo aimed to build a good road between the Central Valley and the Caribbean coast in order to favor both exportation and importation of goods and merchandise. The road to Matina, which dated back to the colonial period, was inadequate and, furthermore, forced the crossing of Reventazón River in an unsafe place near the current town of Siquirres. As a consequence, during the government of Juan Rafael Mora, it was decided to discard this road and look for a better place to cross the river, and it was then that Angostura, in the city of Turrialba, was found. This article documents in a detailed way, and based on the available files from the National Archives as well as newspapers located in the National Library, how this place was discovered, along with the initiatives and the people that made the construction of the four bridges possible in a lapse of 110 years: one made of timber and stone wall, an underroof wooden one, an iron one and the current steel bridge, all built during the governments of Mora (1852), Jesús Jiménez Zamora (1865), Julio Acosta García (1923) and Mario Echandi Jiménez (1962).

1 Doctor en Entomología, graduado de la Universidad de Riverside, California, EE.UU., Profesor Emérito del Centro Agronómico Tropical de Investigación y Enseñanza (CATIE), Costa Rica. Contacto: luko@ice.co.cr
Luko Hilje. Los puentes en Angostura, Turrialba. Revista Comunicación. Año 38, volumen 26, número 2, julio-diciembre, 2017. Instituto Tecnológico de Costa Rica. ISSN: 0379-3974 / e-ISSN1659-3820.

\section{PALABRAS CLAVE:}

Río Reventazón, puentes, Angostura, Turrialba, Costa Rica, Braulio Carrillo, Juan Rafael Mora, Jesús Jiménez, Julio Acosta, Mario Echandi.

\section{KEY WORDS:}

Reventazón river, bridges, Angostura, Turrialba, Costa Rica, Braulio Carrillo, Rafael Mora, Jesús Jiménez, Julio Acosta, Mario Echandi. 


\section{INTRODUCCIÓN}

Nacido en las imponentes alturas de la cordillera de Talamanca, en las cercanías del Cerro de la Muerte, el río Grande desciende hasta las planicies del valle de Orosi y las recorre, incesante y caudaloso (figura 1A), hasta toparse con el río Aguacaliente -fusión del Reventado y el Purires- que vierte sus aguas en su amplio cauce. Ahí cambia de nombre por el de Reventazón. Esta denominación data de la época colonial -cerca de 1630-, cuando el río Grande de Orosi se "reventó" o salió de su lecho hacia la izquierda, en las proximidades del actual Siquirres, y formó un nuevo cauce, lo que justificó el apelativo de "río de la Reventazón" (Molina Montes de Oca, 2005). Después fue bautizado con este epíteto desde ese punto hacia atrás, hasta el propio valle de Orosi.

En sus $145 \mathrm{~km}$ de recorrido -superados en el país tan solo por los 160 km del río Grande de Térrabael Reventazón serpentea, encajonado a través de una topografía escarpada y montañosa (figura 1B), para luego discurrir por llanuras y, a unos $5 \mathrm{~km}$ del litoral, convertirse en tributario del Parismina, que es el que desemboca en el mar Caribe. No obstante, debido a su gran caudal, aún en estos terrenos planos representa un infranqueable obstáculo para transitar desde el Valle Central hasta la costa.

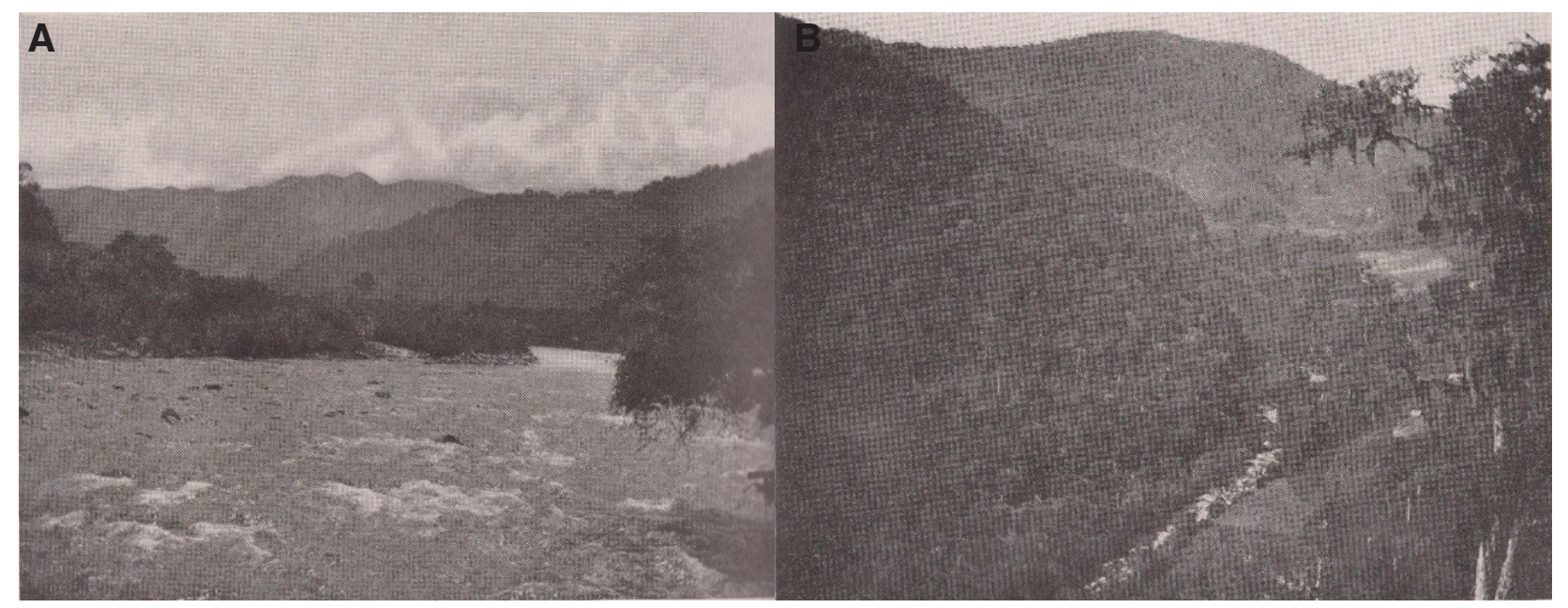

Figura 1. El río Reventazón en 1910, al atravesar el valle de Orosi (A) y en una vista en las cercanías de Juan Viñas (B). Fuente: Calvert y Calvert (1917)

Sin embargo, finalmente fue posible soslayarlo en el sitio hoy denominado Angostura, en Turrialba, con lo que se pudo superar ese impedimento, lo cual sucedió por primera vez a mediados del siglo XIX. Quiénes y cómo lo lograron permanece ignorado en los anales históricos, por lo que en el presente artículo se intenta reconstruir los acontecimientos ocurridos en ese sitio en relación con la construcción de ese y los siguientes puentes que, a lo largo del tiempo, hicieron posible el anhelado tránsito hacia el litoral Caribe.

\section{POR CAMINOS DISTINTOS}

La ubicua presencia de importantes cacicazgos indígenas en las regiones del Caribe y Talamanca, de los cuales incluso se cuenta con mapas aproximados
(Ibarra, 2002), de manera implícita indica que desde tiempos inmemoriales los aborígenes debieron enfrentarse al insalvable obstáculo geográfico impuesto por el cauce del río Reventazón. Abundante en pesca, era una fuente inagotable del exquisito pez bobo (Joturus pichardi), pero era imposible vadearlosobre todo en una zona tan Iluviosa-, lo que limitaba al extremo el desplazamiento para las actividades de cacería y recolección de productos silvestres, así como para el intercambio comercial y social de las diferentes etnias.

Eso explica que los indígenas que habitaban Talamanca optaran por evadirlo, al abrir una trocha que les permitía viajar desde sus dominios en Chirripó hasta la costa. Después se le Ilamaría camino de Tierra Adentro, el cual en Atirro convergía con el camino de Misioneros - no construida por 
ellos, aunque sí transitada después en sus labores de evangelización-, que conducía hasta Tucurrique y Orosi. De ambas rutas se cuenta con un mapa (Ibarra, 1985), además de un testimonio del cronista Jerónimo Benzoni, quien en 1544 acompañó al gobernador Diego Gutiérrez y Toledo en su fatídico viaje desde la costa hasta Tayutic (Benzoni, 1989). Nótese, entonces, que era posible trasladarse desde el valle de Orosi -cuna del Reventazón- hasta la costa sin tener que atravesar el río.

Pero incluso en dicho valle, quizás por las necesidades cotidianas y la densidad de su población, los indígenas habían instalado un puente de hamaca, construido con bejucos. De él se cuenta con un vívido testimonio en un relato del gobernador Francisco Antonio de Carrandi y Menan, quien en 1739 -al regresar de Matina y tras pernoctar en Tucurrique- relataría que llegó "al río de la Hamaca, nombrado el Grande, y es el pasado en el camino de Matina, la Reventazón, y tiene por puente una hamaca de bejucos de 38 y media varas [32 m] de largo, por donde se pasa con gran peligro" (Carrandi y Menan, s.f.).
De hecho, en un croquis del valle de Orosi que data de 1853, un siglo después, se observa un puente sobre el río Grande de Orosi, acompañado con la leyenda Puente de bejucos para pasar a Cachí (Ibarra, 1999). Asimismo, existe una imagen de dicho puente (figura 2), trazada en 1858 por el venezolano Ramón Páez Ricaurte, compañero de aventuras del viajero irlandés Thomas F. Meagher $(2002)^{2}$. En el referido croquis se percibe que estaba muy cerca de donde hoy se extiende un largo puente colgante de metal.

En cuanto a esos hermosos parajes fluviales, describe Meagher (2002) que después de descender desde el actual pueblo de Paraíso, arribaron a "la confluencia de tres ríos: el Navarro, el Agua Caliente y el Naranjo, que corrían veloces a nuestros pies hacia el Río Grande, un río ancho, rápido, brillante, de color verde que divide el valle y va a perderse más allá en el Reventazón, uno de los torrentes más salvajes y bravíos que tienen su nacimiento en las alturas volcánicas de esta región solitaria y soberbia". Y continuaba indicando que "llegamos hasta un puente suspendido, que nadie puede pasar a caballo. Es obra de los indios de Orosi y se llama el puente

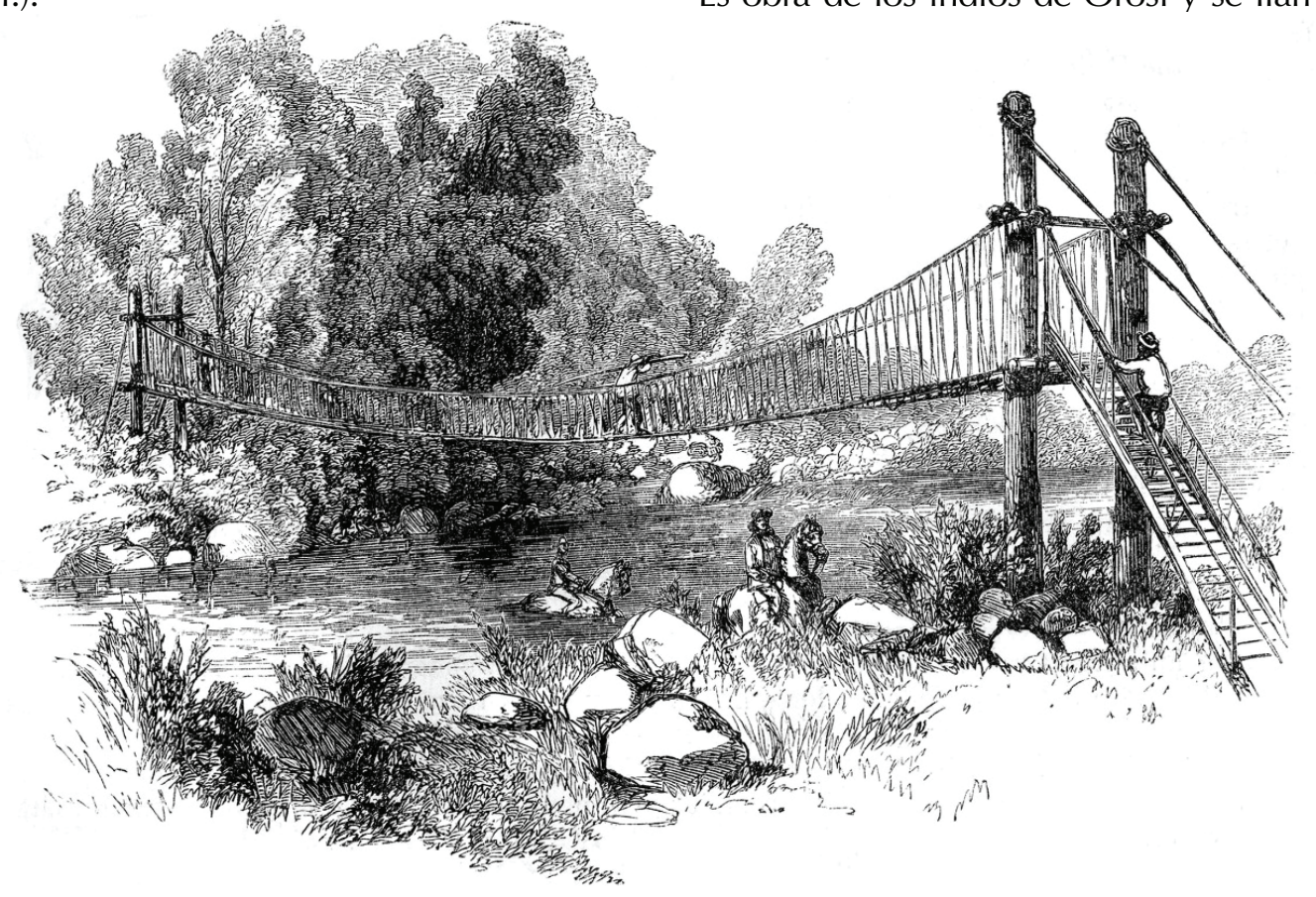

Figura 2. Puente de bejucos sobre el río Reventazón, en Orosi. Fuente: Archivos MHCJS

2 Esta y otras elocuentes imágenes se omitieron en la versión traducida de los relatos de Meagher. No obstante, por fortuna se cuenta ahora con una compilación de la versión facsimilar de los originales (Vargas, 2008). 
de La Hamaca. Hay cuatro postes de la madera más recia, dos en cada orilla del río, y a cuatro pies el uno del otro; estos postes toscos están unidos por cuerdas o cadenas de alambre, y aunque éstas son resistentes y durables, los indios las renuevan cuidadosamente cada cuatro años, porque solo pasando por ese puente pueden ir al valle y volver de él cuando el río está crecido y torrencial".

En concordancia con esta descripción-salvo algunos detalles-, en 1860 el médico y naturalista alemán Alexander von Frantzius (Hilje, 2008) narraría que "aquí vimos, por primera vez, los notables puentes colgantes hechos de bejucos o enredaderas por los indios. Como el material con que estos puentes están elaborados es poco durable, tienen que ser renovados cada año, y son tan fuertes que los indios pueden pasar sobre ellos con sus cargas a las espaldas sin peligro alguno. Se encuentran dos más de estos puentes colgantes en los alrededores de Orosi. Aquí los Ilaman 'puentes de hamaca', pues en efecto parecen hamacas. Constan de tres largos rollos o líos del grosor del brazo de un hombre, hechos de bejucos y unidos a distancias iguales por ataduras transversales. Ambas extremidades del puente están atadas a fuertes postes de árboles; pero es tan exigua la tensión, que el puente, en el medio, cuelga en forma de curva bastante baja. Se camina sobre el rollo o lío más bajo como un acróbata sobre la cuerda o maroma, agarrándose de los otros dos líos laterales, que están más arriba".

Nótese que dicho autor menciona la presencia de tres puentes de hamaca en el valle de Orosi, quizás en el propio río Grande o incluso en el Reventazón. Cabe anotar que también un puente así, pero más extenso y pareciera que de estructura más compleja, fue observado en 1882 por el arqueólogo sueco Carl Bovallius sobre el río Pacuare, del cual incluso se cuenta con un dibujo (Hilje, 2013).

Ahora bien, la red de caminos de los indígenas no necesariamente servía a los intereses de los colonizadores españoles, quienes se asentaron en el Valle Central y después convertirían Cartago en la primera capital de Costa Rica. Por tanto, necesitaban una ruta que comunicara Cartago con el mar Caribe $y$, en particular, con el valle de Matina, excelente para la producción de cacao. Y aunque se podría pensar que podían mejorar y utilizar las veredas indígenas de Tierra Adentro y Misioneros, quizás los puentes de hamaca no funcionarían para el trasiego de mercaderías, a juzgar por el siguiente pasaje del relato de Carrandi al llegar al puente en Orosi: "Aquí me detuve como hora y media, hasta que pasó todo mi equipaje, y las bestias por el río, que las arroja la corriente fuertemente como dos cuadras, de lo que resultan atrasos por traspasarlas lo frígido y golpearlas lo pedregoso del río".

En todo caso, los colonizadores españoles optaron por otra ruta entre Cartago y Matina, cuyas características se conocen hoy gracias al testimonio de Carrandi, que aparece en el informe de una expedición a Matina (Carrandi y Menan, s.f.) para valorar la posibilidad de establecer un fuerte que permitiera defenderse de las frecuentes incursiones de los temibles indios zambo mosquitos. Emprendió este viaje con una comitiva de 71 personas, en 33 mulas cargadas de víveres, el cual duró casi un mes, para cumplir una orden recibida desde la Capitanía General de Guatemala. En dicho informe se capta que para 1739 ya figuraban Juan Viñas, Turrialba, Guayabo y Bonilla entre los ranchos o caseríos que había en la ruta.

Eso sí, cabe destacar que no se podía llegar al valle de Matina sin antes cruzar el río Reventazón y eso era posible apenas la topografía lo permitiera, lo cual ocurría en las proximidades de la actual Siquirres, en el Ilamado paso de La Aduana o La Canoa (figura 3). Ese punto se denominaba así porque era necesario atravesar el río en canoa, a veces por unos $100 \mathrm{~m}$ y en medio de fuertes corrientes, a riesgo de la vida de los viajeros y de perder los cargamentos que portaban. En ese sitio, en las cercanías de La Junta, hoy reposa un vetusto puente ferroviario de dos cuerpos, de 198 m de extensión.

A pesar del serio inconveniente de arriesgarse a cruzar el turbulento Reventazón, el camino a Matina se mantuvo como la vía oficial entre Cartago y Matina. No sería sino un siglo después -en 1838- que el Jefe de Estado Manuel Aguilar Chacón contrató al ingeniero inglés Henry Cooper para que hiciera un reconocimiento de dicha ruta y determinara si se podía adaptar para el tránsito de carretas, o si sería preferible abrir otra ruta en sus cercanías.

Cooper cumplió su labor y presentó un minucioso informe (Cooper, 1896), pero Aguilar fue derrocado por Braulio Carrillo Colina y este otorgó el contrato a 


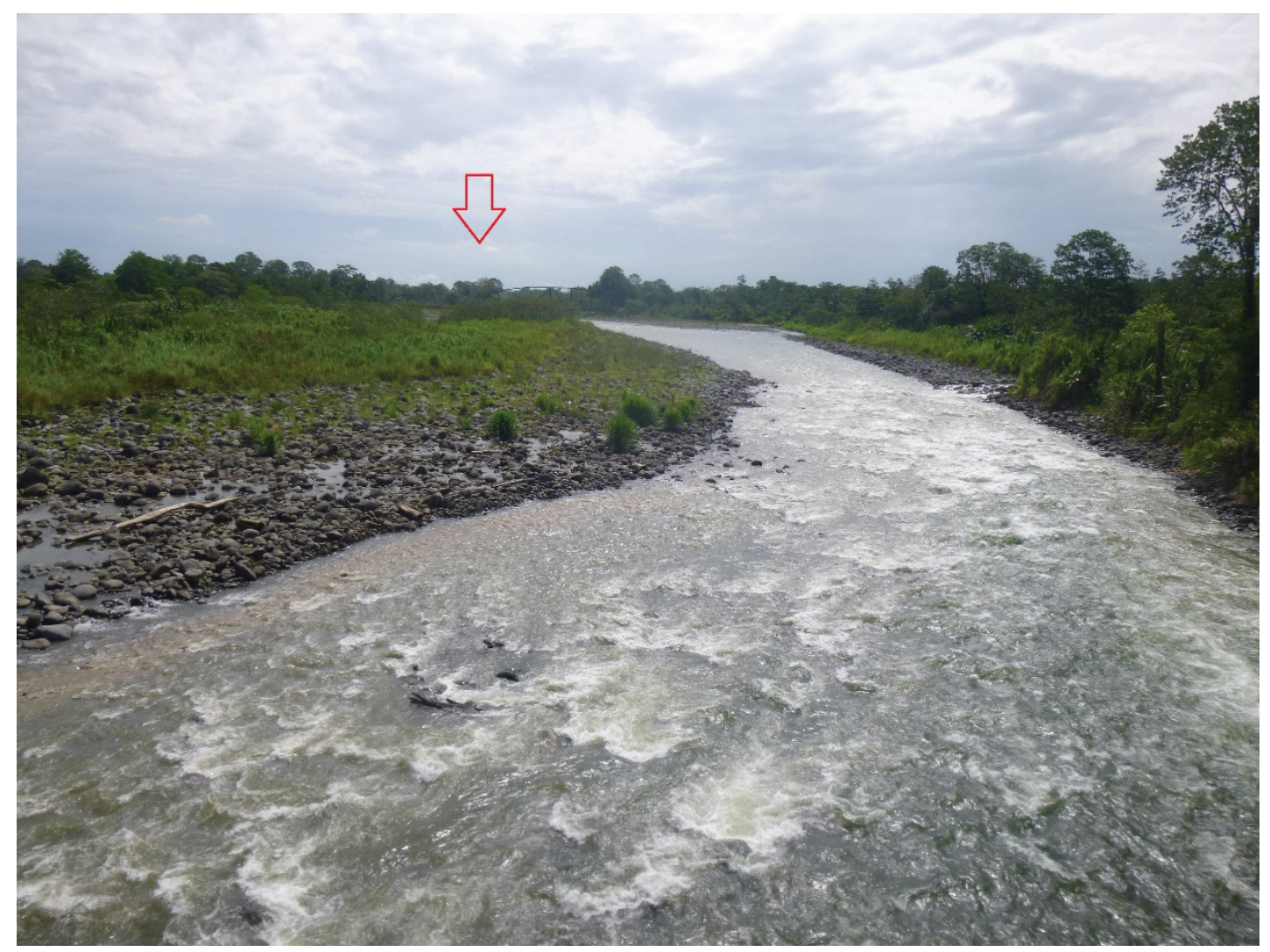

Figura 3. El río Reventazón cerca de La Junta, en época de bajo caudal.

La flecha indica la ubicación del puente ferroviario. Fuente: Luko Hilje

Narciso Esquivel Salazar y después a Joaquín Iglesias Vidamartel (Obregón, 1989). Aunque se optó por construir una nueva ruta, debido a las condiciones del terreno y los costos económicos implicados, después se decidió mejorar la vereda existente y cuando ya se había avanzado unos $63 \mathrm{~km}$, Carrillo fue derrocado por el general hondureño Francisco Morazán Quesada, quien lo descontinuó.

\section{EL DESCUBRIMIENTO DE ANGOSTURA}

En realidad, en la visión de Carrillo convergían la aptitud de Matina como zona cacaotera con la necesidad de aligerar la exportación de café hacia Europa, así como la importación de mercaderías desde allá. A su vez, esto permitiría reducir de manera sustancial los muy altos costos de los fletes. En aquella época el trasiego de estos bienes debía hacerse desde Puntarenas, lo que consumía casi cuatro veces más de travesía marítima, además de los consabidos peligros propios del Cabo de Hornos, pues los barcos debían dar la vuelta por América del Sur.

Ese anhelo de Carrillo se reavivó con fuerza durante la administración de Juan Rafael Mora Porras -a quien el pueblo llamaba don Juanito- y tanto, que no habían transcurrido seis meses de su ascenso a la presidencia de la República cuando decidió impulsar el camino a Matina. Con ese fin, mediante un decreto del 27 de junio de 1850 quedó establecida la Sociedad Itineraria del Norte, un ente privado de interés público asentado en Cartago, para que acometiera la construcción de esa obra (La Gaceta, 13 y 27 de julio de 1850).

Tal era la importancia del río Reventazón en este proyecto, como obstáculo que había que superar, que uno de los elementos del emblema de esta sociedad era el nombre Reventazón al lado del dibujo del curso de un río. $Y$, en concordancia con esto, había que buscar la manera de atravesarlo, para poder construir el camino hacia el Caribe. Pero 
definitivamente, había que buscar una alternativa al antiguo camino a Matina, ya que con las tecnologías de la época no era posible erigir un puente para carretas en tan vasto cauce. Por tanto, urgía hallar un punto estrecho, donde fuera viable cruzar dicho río mediante un puente corto, para después delinear el nuevo camino siguiendo la ribera derecha del río Reventazón.

Así, a fines de diciembre de 1850, la junta directiva de la Sociedad Itineraria acordó contratar una cuadrilla para "examinar todos los puntos en donde el río Reventazón presente posibilidad de que se le construya un puente sólido, reconociéndolo desde el paso de Urasca hasta más abajo de la confluencia del río Pejivalle" (Archivo Nacional de Costa Rica, 1850). Además, se resolvió que su líder fuera un individuo con "suficiente capacidad para medir la anchura de los diversos puntos en que el río presente la posibilidad deseada, y que pueda dar razón informativa de ello" (Archivo Nacional de Costa Rica, 1850).

En pos de ese objetivo, en los días subsiguientes partió de Cartago un grupo de expedicionarios bajo la guía de Antolín Quesada, la cual recorrió la ribera izquierda del río a partir de Urasca, en el valle de Orosi, hasta Turrialba; así consta en el informe de labores de 1851 de la Sociedad. Tras una semana de fatigas, pero jubilosa, la comitiva retornó para informar que "a más de las [ya conocidas] angosturas de Urasca y Fajardo, había descubierto otras dos en dicho río, casi en frente de Turrialba" (Sociedad Itineraria del Norte, 1852).

Por cierto, cabe preguntarse si -por la estrechez del cauce del río- no sería en Urasca y Fajardo donde estaban los otros dos puentes de hamaca mencionados por von Frantzius. Sin embargo, en Fajardo había otro tipo de puente, como consta en un informe del gobernador de Cartago, Telésforo Peralta López del Corral, que data de 1846. En él se alude al "río Ilamado Fajardo [¿Reventazón?], compuesto de los ríos Macho y Aguacaliente, y muy riesgoso porque su puente es construido de dos vigas, costeadas por los indígenas del citado pueblo [Tucurrique]" (Archivo Nacional de Costa Rica, 29 de setiembre de 1846).

Otra duda que surge es cómo se comunicaban e intercambiaban bienes los indígenas que vivían en Tuis y Talamanca con los que residían en las cercanías de la actual ciudad de Turrialba, en los antiguos poblados de Turriarva la Grande y Turriarva la Chica (Ibarra, 1985), para lo cual debían cruzar el río Reventazón. Sería lógico suponer que lo hacían por alguna de las dos angosturas halladas por Quesada y, de ser así, un puente de hamaca habría sido muy funcional. Pero no existía, pues este explorador lo habría observado. Además, si hubieran colocado troncos sobre la gran roca que había en la angostura de aguas arriba -a la que se aludirá en detalle pronto-, Quesada también los habría visto. En todo caso, en su mapa Ibarra (1985) muestra un camino, casi recto, que comunicaba Turrialba con Atirro, pero sin pasar por Angostura, sino un poco hacia el suroeste.

Para retornar a la expedición de Quesada y ayudantes, enterada de su hallazgo la junta directiva de la Sociedad, decidió organizar una gira confirmatoria, que partió de Cartago el 15 de enero de 1851. En ella participó como líder Francisco María Oreamuno Bonilla, vicepresidente de la Sociedad y también vicepresidente de la República, junto con algunos "prácticos y albañiles", entre quienes figuraron Quesada, José Córdoba, Juan Román y Dolores Ortega. Por fortuna, Oreamuno legó un detallado y esclarecedor relato de la expedición (Archivo Nacional de Costa Rica, 1851).

De dicho informe, el cual aparece completo en Hilje (en prensa), cabe destacar que el grupo no siguió el trillo abierto por Quesada y ayudantes en el viaje previo, sino que tomó el viejo camino de Cartago a Matina para -desde Turrialba- aproximarse al Reventazón; esto les costó penurias y demoras, pero por fin lograron su cometido. Asimismo, las angosturas estaban tan cerca entre sí, que en medio se formaba una especie de extensa poza. Con base en el informe de Oreamuno, la directiva de la Sociedad Itineraria acotaría que "dos angosturas se encontraron en el río, casi al sur de Turrialba: una de ellas con veintitrés varas de claro, por entre la cual se estrecha y pasa el río, y otra de dos caños entre los cuales se reparten las aguas, y con la comodidad para levantar encima de ellos un puente de dos o tres ojos, de diez varas próximamente cada uno" (Sociedad Itineraria del Norte, 1852). En realidad, según esta información, en ambos puntos era posible soslayar 


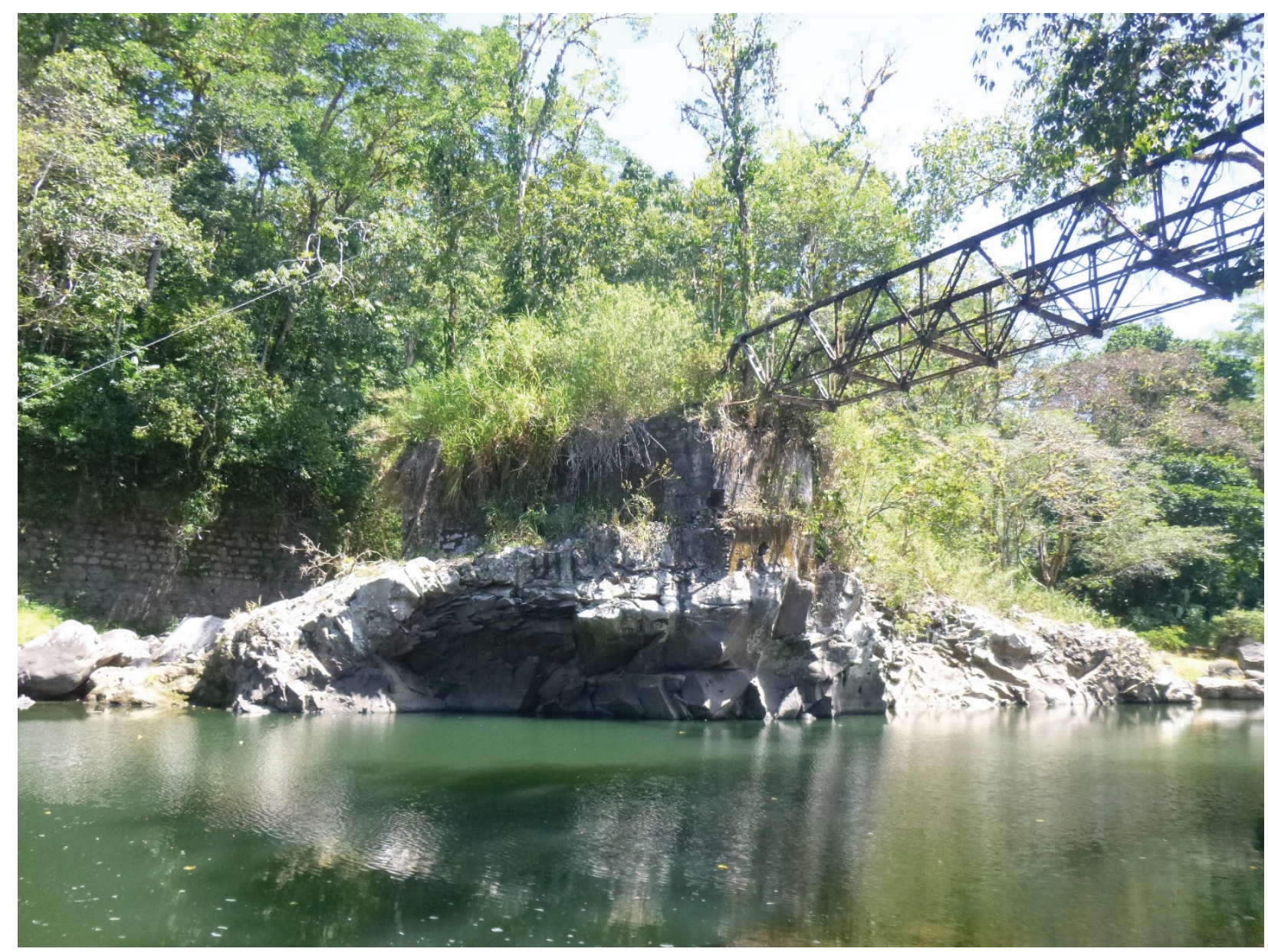

Figura 4. Gran roca en el cauce del río Reventazón. Fuente: Luko Hilje

el río mediante un puente de unos 20 m de longitud, pero en el punto ubicado aguas arriba había una inmensa roca en medio del cauce del río (figura 4), que era un bastión natural y suficientemente amplio y firme para erigir el anhelado puente.

Como una curiosidad, conviene indicar que tras caminar el autor de este artículo, un trecho de más de $500 \mathrm{~m}$ por el mermado río de hoy -como consecuencia de la construcción de la represa de Angostura- hasta poco después de donde desemboca la quebrada de El Poró, en forma de una pequeña caída de agua, la búsqueda de la angostura de aguas abajo resultó fallida. Más bien, de ahí hacia adelante hay altos taludes que impedirían conectar ambas riberas. Asimismo, al observar en detalle esa área en una imagen de satélite, no se percibe ningún punto como el descrito por Oreamuno. Todo esto sugiere que, en siglo y medio, la morfología de la ribera del río ha cambiado mucho y que la angostura de aguas abajo desapareció.

\section{UN PUENTE DE TRONCOS Y CALICANTO}

Ahora bien, en relación con el puente, la junta directiva de la Sociedad Itineraria (1852) descartó construir una estructura firme, "de dos o tres arcos de cal y canto", quizás como el puente que existía en el río Virilla, en San José (figura 5), debido a su alto costo y la urgente necesidad de atravesar el Reventazón para continuar las obras del camino hasta el río Pacuare, en la primera etapa del proyecto del camino. Esta consideración condujo a tomar la decisión de levantar "un puente que, aunque provisional, por ser de vigas, no careciese de solidez, y pudiese servir algunos años" (Sociedad Itineraria, 1852). Por cierto, en el informe anual de la Sociedad se menciona que esto se haría en "la angostura de 
abajo", para aprovechar la gran roca ya citada. Pero aquí hay un error, a juzgar por el relato de Oreamuno, quien con claridad ubica ese punto aguas arriba.

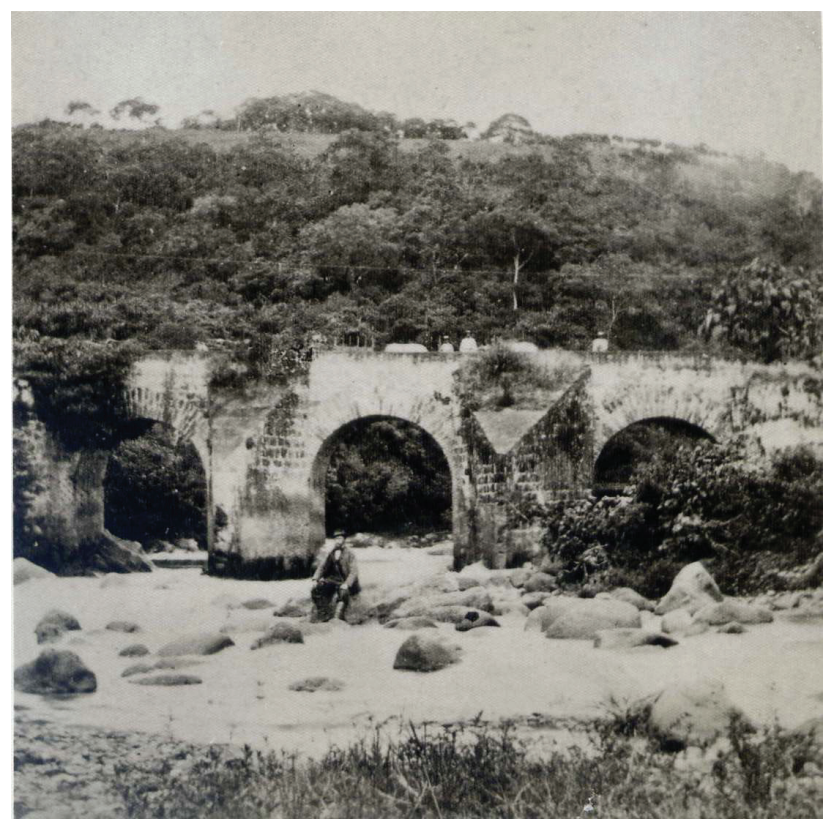

Figura 5. Puente sobre el río Virilla, en el límite entre San José y Heredia. Fuente: Otto Siemon

Cabe señalar que, según consta en varias actas, el encargado de diseñar e instalar el puente era Buenaventura Espinach Gual, presidente de la Sociedad Itineraria. Residente en Cartago, este catalán era un empresario cafetalero que había construido su capital inicial gracias a la extracción de oro en los Montes del Aguacate. No debe confundírsele con su hermano José Ventura, Ilegado a nuestro país posteriormente, quien era un reputado médico.

En cuanto a las características del puente, la junta directiva había acordado "prevenir al mandador que dicho puente se haga de árboles redondos, que tengan suficiente grueso, para que su resistencia equivalga a la de una viga cuadrada proporcionada al tamaño del puente: que sobre dichos árboles debe formarse un encamastrado fuerte, y cubrirse todo con cascajo para emparejar el piso" (Archivo Nacional de Costa Rica, 25 de mayo de 1851). A esta descripción se hará referencia posteriormente.

Es de suponer que para su construcción se utilizaron árboles de espavel (Anacardium excelsum), que es bastante común aún hoy en la ribera del río. Esta especie forma fustes muy rectos, homogéneos, redondos y gruesos, así como con pocas ramas bajas, lo que facilitaba las cosas, pero su inconveniente era que la madera es un poco suave ${ }^{3}$. No obstante, debe recordarse que el puente era provisional.

Para evitar la complicación de trasladar los troncos en una cuenca tan escabrosa y de muy densa vegetación, tal vez ahí mismo había algunos de la longitud y el diámetro adecuados, en una pequeña planicie o rellano que hay en la margen derecha del río. Quizás volteados con hacha, como no se contaba con un aserradero -los había hidráulicos en las muy lejanas Grecia y Puntarenas, hasta donde se sabe-, a lo mejor se usaron tronzadoras, que son grandes sierras manuales con un mango en cada extremo, accionadas por dos hombres. Ello permitía cortar las trozas en la longitud requerida, tanto para los gruesos troncos longitudinales como para los tablones transversales que conformaban la estructura.

La construcción del puente comenzó a fines de mayo. El mandador -se ignora si Arcadio Quirós o Ramón Pereira, pues ambos desempeñaron dicho puesto en esa época- advirtió a la junta directiva de la Sociedad que habría dificultades, lo que haría necesaria "la formación de dos bastiones, uno a cada lado del río". Pero, para reducir costos y dado que era un puente apenas provisional, se decidió utilizar "horcones fijos en una y otra orilla del río, sobre los cuales, enyugados en la forma que preste mayor seguridad, se coloquen los árboles o listones que van a sustentar el piso del puente"; además, esto debía hacerse "cavando en la peña viva los hoyos en que deben clavarse los horcones" (Archivo Nacional de Costa Rica, $1^{\circ}$ de junio de 1851).

Es de suponer que con dos horcones en cada ribera se podría contar con las cuatro horquetas necesarias para insertar y afirmar los largos troncos longitudinales o vigas que, proyectados hacia una y otra ribera a partir de la gran roca que hay en medio del cauce, soportarían los tablones transversales que conformarían la estructura del puente. Sin embargo, apenas una semana después de la decisión previa y por medio de Espinach, el mandador comunicó a la directiva que eso no era conveniente, dada la gran dificultad de fijar los horcones a las rocas, además de que el costo entre ellos y los bastiones no difería mucho. En el acta consta "que el costo que él calculó

3 Información suministrada por el botánico Quírico Jiménez. 
debe impenderse adoptando tal construcción, será con poca diferencia igual al que deba hacerse si se construyeran dos bastiones de cal y piedra, conforme propuso de antemano, por la dureza de la roca en que deben clavarse los horcones y la disposición incómoda de las peñas del río, teniendo además la construcción sobre horcones el inconveniente de dejar todavía demasiada anchura al cauce, cuando con los bastiones propuestos puede estrechársele" (Archivo Nacional de Costa Rica, 8 de junio de 1851). En consecuencia, y persuadidos de esta idea, en dicha sesión se acordó "fabricar un bastión de cal y canto en cada una de las orillas del río".

Como confirmación de lo resuelto, en el citado informe de labores de 1851, se lee lo siguiente: "No pudo [la Sociedad] prescindir de levantar bastiones de cal y piedra, a uno y otro lado del río, porque siendo éste tan caudaloso, y teniendo en los tiempos de Iluvia grandes avenidas, no bastaban sus peñas naturales, a pesar de ser altas, para impedir que se desbordase, y en una de tantas crecientes se llevase las vigas que debían formar el referido puente". Llama la atención que no se mencione ningún bastión colocado sobre la gran peña ubicada en el cauce del río. Asimismo, nótese que el término desbordarse se refiere más bien a un caudal excesivo que, por su misma fuerza, podría desprender el puente de sus soportes en las rocas, lo que obligaba a incrementar la altura de sus bases. Para levantar los bastiones requeridos, a mediados de julio se contrataron dos albañiles y como estímulo se les pagaban uno o dos reales diarios más de lo que ganaban en Cartago.

Un mes después, según consta en un acta, las labores avanzaban "sin contratiempo alguno" y para fines de setiembre, es decir, un mes y medio después de esta noticia, todo estaba listo para la instalación del puente, por lo que Espinach se desplazó hasta Turrialba para dirigir las operaciones (Archivo Nacional de Costa Rica, 28 de setiembre de 1851). Sin embargo, hubo problemas técnicos para instalarlo, en lo que se calificó como "el resultado desgraciado de la tentativa que se hizo para la colocación del puente", dado que los bastiones no tenían la altura requerida, ante lo cual él regresó a Cartago. Cabe suponer que esto provocó roces con el mandador Arcadio Quirós y que quizás incluso renunció, pero a inicios de enero de 1852 se le recontrató, premiándolo incluso con dos pesos mensuales más, "con cuyo aumento ha ofrecido volver".

En la siguiente sesión de la junta directiva se acordó incrementar su altura, así como autorizar a Espinach para comprar "los útiles que crea necesarios para verificar a su tiempo la colocación del puente", además de darle un voto de confianza por sus meritorias labores en tan relevante proyecto (Archivo Nacional de Costa Rica, 12 y 15 de octubre de 1851).

A inicios de diciembre, Espinach informaba que los bastiones ya estaban listos, pero que ahora el problema era que no habían podido conseguir "un cable grueso de cáñamo, de cuarenta brazas de largo que había pedido a Puntarenas, para suspender las vigas". No obstante, por fortuna, "fue informado de que en dicho puerto hay cables de mayor dimensión, [por lo que] ha dado sus órdenes para que se compre uno y se remita cuanto antes a esta ciudad" (Archivo Nacional de Costa Rica, 7 de diciembre de 1851). En congruencia con esto, para la fecha en que el secretario de la Sociedad escribió el informe de labores desarrolladas en 1851, anotó que "solo falta ya para que esta obra quede enteramente acabada, que llegue un cable grueso de cáñamo, que se ha pedido a Puntarenas, para suspender con él las vigas que deben servir de piso y colocarlas en su respectivo lugar".

Estos cordeles, que quizás se utilizaban para remolcar o sujetar embarcaciones -aunque en Puntarenas aún no había muelle-, deben haber llegado de manera oportuna, pues a inicios de febrero Espinach comunicaba a la directiva "haber colocado las siete vigas que forman el puente del Reventazón" (Archivo Nacional de Costa Rica, 2 de febrero de 1852). En respuesta, se acordó expresarle las gracias y que "se dé un breve manifiesto impreso, participando a los accionistas tan feliz resultado". De hecho, en una especie de apéndice del informe de la Sociedad, fechado el 2 de febrero de 1852 -la misma fecha en que Espinach comunicó su logro-, se expresaba que "se ha colocado ya un puente de vigas sobre el Reventazón, sostenido por bastiones de cal y piedra, y de suficiente anchura no solo para el tránsito de mulas, sino también para el de carruajes, si fuese necesario". Dos días después, con justicia la directiva manifestaba a Espinach sus "expresivas gracias por los importantes servicios que incesantemente hace 
U. a la Junta" (Archivo Nacional de Costa Rica, 4 de febrero de 1852).

Ante tan significativo logro, con presteza la prensa hizo eco de la satisfacción popular en un artículo que, con el nombre "Junta Itineraria del Norte. Puente del Reventazón", detallaba que "se ha construido uno hermoso, con vigas de 26 varas de longitud, y aunque no son comunes en Centro América obras de esta clase, con toda la maestría del Señor Don Buenaventura Espinach, pudo levantar por el aire tan enormes vigas y ponerlas como por la mano, sin dañar los bastiones que estaban recién construidos, valiéndose de todos los aparatos que emplean los ingenieros para obras semejantes" (La Gaceta, 14 de febrero de 1852). Nótese que se menciona tan solo la sección más extensa del puente, lo cual sugiere que la más corta estaba formada por piezas cuya colocación no fue una labor complicada. Por otra parte, cabe acotar que la longitud de las piezas citadas -de unos $22 \mathrm{~m}$ - coincide bastante con los 20,6 m previstos en un diseño de puente elaborado en 1942, al que se aludirá posteriormente.

Cuesta imaginar cómo se manipulaban las muy pesadas piezas de madera en un espacio tan reducido y peligroso, además de que no se contaba con grúas y tal vez ni siquiera con poleas, aunque en la citada noticia se menciona el uso de aparatos de ingeniería. La mención del grueso cordel traído de Puntarenas sugiere que -mediante un juego de esta y otras cuerdas- colocadas en varios sentidos y quizás apoyadas en las horquetas formadas por las ramas de algunos árboles cercanos fue posible levantar en vilo las piezas para colocarlas con precisión sobre los bastiones. Una verdadera proeza de Espinach y colaboradores.

A partir de entonces, no se tiene información sobre el puente, excepto que -apenas tres meses después de su instalación- cuando a fines de mayo de 1852 visitó el puente el barón Alexander von Bülow, futuro socio de dicho ente y a quien se aludirá después con mayor detalle, comentó que "cree que se va a quebrar muy pronto". Ante tan preocupante juicio, la directiva de la Sociedad solicitó al mandador "que haga quitar de encima del puente la tierra, cascajo, y cualquier otra cosa cuyo peso pueda perjudicar, procurando componer provisionalmente el piso del puente sin cargarle mucho peso, mientras se consigue asegurarlo" (Archivo Nacional de Costa Rica, 30 de mayo de 1852).

Es interesante indicar que, cuando a mediados de 1853 el viajero alemán Wilhelm Marr visitó Angostura, relataría que "sobre el río y entre dos rocas estaban colocados largos troncos de árboles y vigas atravesadas encima de éstos", para de inmediato indicar que "el improvisado puente oscilaba de tal modo sobre el rugiente recial, que preferimos desmontarnos, echar las mulas por delante y pasar a pie esta 'oubliette' que se mece en el aire". Este vocablo francés alude a un tipo de trampa en los castillos medievales y Marr (2002) lo utiliza de manera burlesca -como era usual en él- para referirse a lo inseguro que era. La descripción de Marr sugiere que el puente original, con apenas un año de uso, se había desarmado bastante, al punto de que no se podía cruzar en carreta ni a lomo de mula.

Conviene resaltar que, con excepción de este testimonio de Marr, no se cuenta con una descripción del aspecto del puente completo. Nótese que usa el término viga, pero este podría ser un error de traducción, pues en sentido estricto una viga es una pieza larga y gruesa que se utiliza en la armazón de los techos de casas y edificios. En los documentos de la Sociedad se emplea para referirse a los largos troncos longitudinales del puente, como se vio previamente; es decir, las piezas transversales no podían corresponder a vigas, sino quizás a los listones mencionados. En consulta con la persona que tradujo el texto de Marr, este escribió "querbalken", que se podría traducir como vigas o palos atravesados, por lo que tablón podría ser un término adecuado 4 .

Es menester aclarar que un listón es una pieza rectangular grande, equivalente a un tablón. Aunque ahí era sumamente difícil obtener este tipo de piezas -si no imposible, por carecerse de un aserradero-, tal vez se podían obtener con el empleo de tronzadoras, a pesar de ser una labor muy difícil y pesada para los operarios, por lo que quizás se podían obtener piezas rústicas, no del todo parejas.

Ahora bien, cabe suponer que se necesitaban unos pocos tablones, tal vez cuatro, para dar firmeza a toda la estructura, pero subsiste la duda de cómo estaban sujetados a las vigas longitudinales. La posibilidad

$4 \quad$ Esta aclaración se debe a Irene Reinhold. 
más obvia era el uso de grandes pernos lisos o incluso de tornillos sin tuerca, que atravesaran por completo cada tablón y se pudieran insertar profundamente en cada una de las siete vigas. Sin embargo, de no existir esas piezas metálicas, es posible pensar en otra opción, bastante laboriosa, aunque parecida a una técnica usada en aquella época para construir viviendas. Para ello había que hacer profundos cortes en las vigas y formar muescas en cada una -del ancho y profundidad de los tablones-, de modo que una vez alineadas las siete vigas se pudiera insertar o acoplar cada tablón o listón -en el léxico de la Sociedad- de manera transversal. Quizás a esto se aludía en las actas de la Sociedad al mencionar "un encamastrado fuerte", término que no existe, pero que se refiere a la emulación de un camastro o catre; Sí existe la palabra encamonado en el mundo de la arquitectura, referido a una armazón de listones. Y para rellenar los surcos formados entre las vigas contiguas y facilitar el tránsito de las carretas se rellenaban estos con cascajo y tierra.

Para concluir lo referido a este primer puente, como en aquella época no había un camino entre Turrialba y este sitio, conocido como La Angostura desde ese mismo momento, en el citado informe se indica que "fue necesario abrir uno, que pasa por la hacienda del Sr. D. Manuel Gutiérrez, y por terrenos del Presbítero D. Juan Andrés Bonilla [Monge], y que aproximadamente tendrá dos leguas de largo ${ }^{5}$. Aunque con el carácter de provisional, está expedito para mulas, tanto que ha servido para el acarreo de la piedra de cal que se ha conducido para la construcción del puente". En cuanto a la distancia mencionada, que corresponde a unos $8,5 \mathrm{~km}$, en realidad es de exactamente $7,9 \mathrm{~km}$ desde el actual salón Mon Río hasta el puente en Angostura.

$\mathrm{Si}$ bien en un acta se anota que la piedra caliza se traía de Turrialba, es de suponer que más bien se extraía en Azul o en Ánimas, en la ruta hacia Matina, donde aún hay importantes tajos en explotación. Tan difícil era conseguir arrieros que trasportaran este material que debió pagárseles "hasta seis reales de flete por cada carga de piedra" (Archivo Nacional de Costa Rica, 15 de junio de 1851).

$5 \quad$ En Hilje (en prensa) hay abundantes evidencias de que el primer individuo era más bien el empresario cartaginés Francisco de Paula Gutiérrez Peñamonge.

\section{UN PUENTE DE ARCOS Y TECHADO}

Se podría aseverar que el citado puente no había terminado de afianzarse sobre sus bastiones, cuando en el horizonte apareció un extraordinario socio para la Sociedad Itineraria, en su proyecto de construir un camino entre Cartago y la costa caribeña. Se trataba de la Sociedad Berlinesa de Colonización para Centro América, representada por el barón Alexander von Bülow von Schonberg, a quien ya se aludió.

Esta cuestión ha sido abordada ampliamente por Hilje (en prensa). Sin embargo, en pocas palabras, debido al gran potencial geoestratégico que significaba para Alemania la región centroamericana, el objetivo inicial de dicha Sociedad era establecer una colonia alemana en territorio costarricense, para lo cual von Bülow firmó un contrato con el gobierno de don Juanito Mora el 7 de mayo de 1852, el cual fue aprobado por el Congreso una semana después (La Gaceta, 19 de junio de 1852). ${ }^{6}$ La Sociedad Berlinesa se decidió por Turrialba, pues la localización de la colonia en ese sitio ofrecía las condiciones para unirla con un posible camino al litoral Caribe, con numerosas ventajas. Enterado al respecto von Bülow del proyecto de la Sociedad Itineraria, pronto negoció con sus miembros y así se concretó una importante alianza entre ambas entidades.

En los meses subsiguientes, von Bülow eligió un área de la ribera derecha del río Reventazón, la deforestó y construyó una casa de troncos, que servía de residencia y oficina, desde donde se empezó a planificar la colonia. Como parte de estas actividades, pronto se percataron de que era necesario construir un puente sólido, apto para carretas, por lo que el ingeniero de la colonia, Francisco Kurtze, se propuso diseñar uno. Él preparó el plano, el cual incluso fue aprobado en setiembre por la Sociedad Itineraria y remitido a von Bülow, "para que se sirva providenciar su pronta ejecución", lo cual no ocurriría (Archivo Nacional de Costa Rica, 26 de setiembre de 1852). En realidad, el proyecto del camino y la colonia abortaron, debido a serios errores de cálculo y ya para mediados de 1854 había expirado. Por tanto, por

$6 \quad$ Este acuerdo aparece citado como el decreto LXV (p. 145), dentro de la Colección de las leyes, decretos y órdenes expedidos por los Supremos Poderes Legislativo y Ejecutivo de Costa-Rica, en los años de 1851, 1852 y 1853. (1861). Tomo XII. Imprenta de la Paz. 
muchos años permaneció ahí el puente construido por Espinach y el plano guardado en algún lugar.

Con la llegada al poder en 1863 del médico cartaginés Jesús Jiménez Zamora, se retomó el proyecto del camino a Limón y Kurtze fue nombrado Director de Obras Públicas. Cabe acotar que Jiménez había sido directivo de la Sociedad Itineraria, además de que tanto él como Kurtze -gran conocedor del Caribetuvieron propiedades en Turrialba. El proyecto avanzó a paso firme y, por fin, Kurtze pudo desempolvar el plano y edificar su ansiada obra.

Así, ya en marzo de 1865 se inauguraba el puente que Kurtze había diseñado, además de un tramo del camino, de Angostura a Cacao (La Gaceta, 8 de abril de 1865). En este sitio, a 13,5 km de Angostura, había un rancho, en el punto en que dicha carretera cruzaba la quebrada del Frijolar o Cacao Chiquito, cerca de donde hoy están los caseríos de La Flor y Pilón de Azúcar (Archivo Nacional de Costa Rica,
1864). Para tan importante acontecimiento viajó hacia Angostura una comitiva de unas 40 personas, entre las que figuraba el presidente Jiménez, su esposa y algunos familiares; además, la conformaban los encargados de negocios de EE.UU. y España, así como el cónsul de España.

El citado puente estaba donde hoy yacen los vestigios de un puente de metal inaugurado en 1923 (figura 6), al cual se hará referencia en detalle posteriormente. Su construcción fue dirigida por el suizo Roque o Rocco Adamini -víctima de una enfermedad, no pudo ver culminada la obra-, mientras que los aspectos de carpintería correspondieron al alemán Eduardo Steffen Grigat-no Steffens, como se ha perpetuado en la literatura- y los de masonería o albañilería al cartaginés Valerio Pérez (Archivo Nacional de Costa Rica, 1866).

El puente consistía en dos secciones con forma de arco aéreo o cercha; la primera de $10 \mathrm{~m}$ de longitud y 5,5 m de ancho, y la otra de $21 \mathrm{~m}$ y $4,5 \mathrm{~m}$. Estaban montadas sobre tres grandes bastiones de mam-

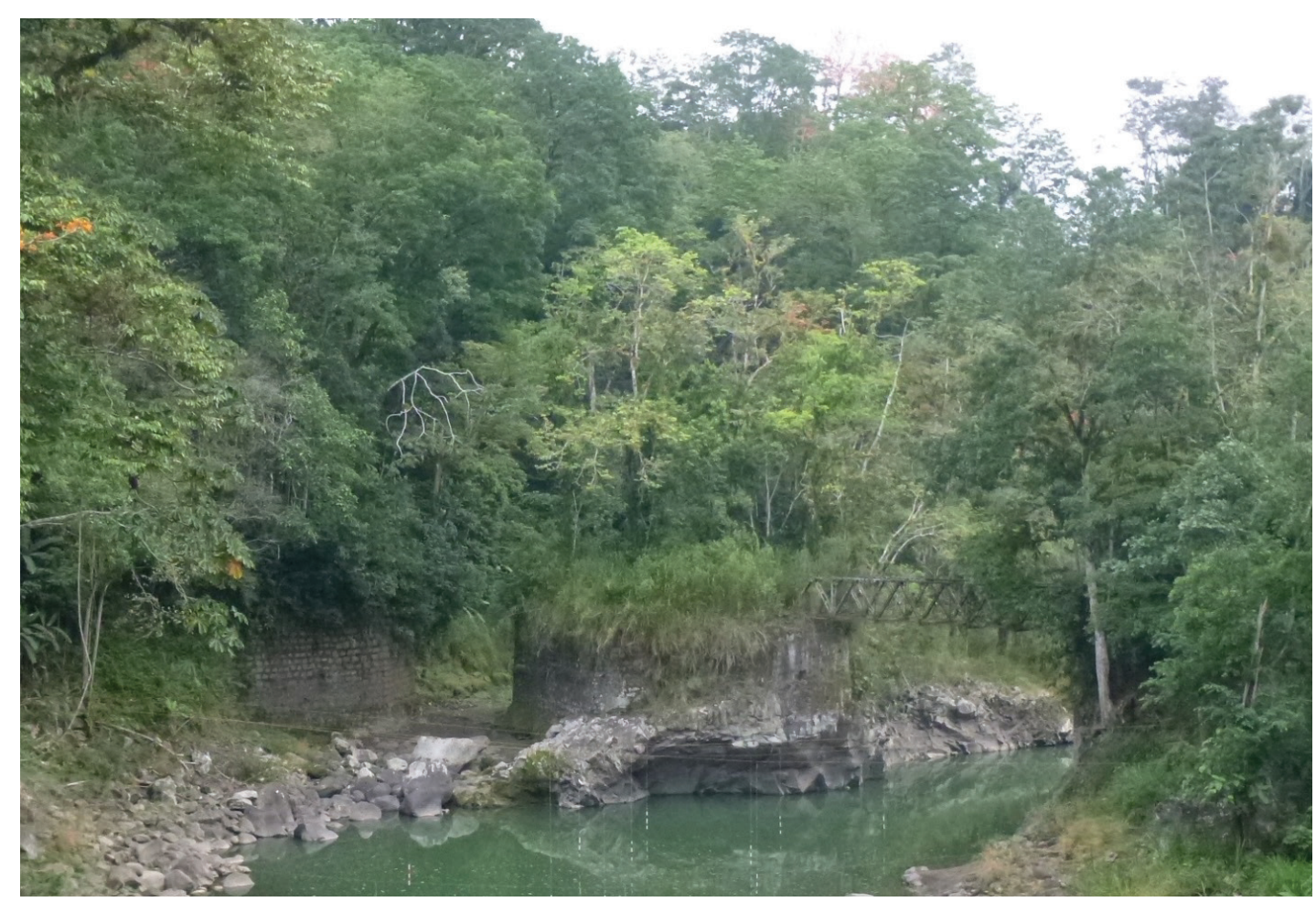

Figura 6. Paraje donde Kurtze construyó el puente. Nótense los bastiones erigidos sobre la roca central y las de ambas riberas. Fuente: Luko Hilje

$7 \quad$ Este plano catastral data de 1864 y fue elaborado por el alemán von Chamier. Por cierto, con el nombre Piedra Grande o Pan de Azúcar, ahí aparece el actual Pilón de Azúcar. 
postería, aún presentes, para que se elevara casi 14 $\mathrm{m}$ sobre el nivel del agua. Se ignora si los primeros bastiones, construidos por Espinach, fueron eliminados o apenas modificados. Asimismo, en previsión de que durara unos 30-35 años, fue pintado con tres manos de alquitrán, lo cual debía repetirse cada año, y cubierto con techumbre de tejamanil; este corresponde a tablitas pequeñas, parecidas a tejas, quizás de la muy resistente madera de pejibaye.

Es oportuno hacer una digresión aquí para indicar que en aquellos tiempos la norma era hacer puentes de calicanto, que era un tipo de construcción sólida, de piedras de río unidas por argamasa, correspondiente a una mezcla de arena y cal. Esta era una técnica constructiva medieval para puentes, muros, edificios, etc. Para puentes pequeños, en cada orilla o banco se instalaba un bastión de calicanto, como una especie de muro, en el mismo sentido de la corriente. Sobre ellos se colocaban vigas árboles de madera dura, resistente a la pudrición. Sin embargo, en el caso de Angostura, al mencionar Kurtze que se trataba de un puente de mampostería, ello significa que en vez de argamasa se usó cemento y arena para unir las piedras, y quizás incluso algo de hierro, aunque en los bastiones actuales no se observan metales ${ }^{8}$.

Cabe agregar que dicho puente fue inaugurado el lunes 27 de marzo de 1865. Para ello la comitiva del presidente Jiménez salió de Cartago el sábado, y en Naranjo -hoy Juan Viñas- fue recibida bajo arcos de palmas, con repiques de campana y disparos al aire, a los que se sumaron un almuerzo ofrecido por el cafetalero francés Luciano Tartiére, así como varios actos culturales por la tarde y la noche, los cuales culminaron con una serenata. Después de pernoctar ahí, partieron a las nueve de la mañana del domingo. En Turrialba almorzaron donde el acaudalado cartaginés José Ramón Rojas Troyo - dueño de la hacienda Guayabo en una época-, para llegar a Angostura a la una y media de la tarde. Había un ambiente de gran vistosidad y emotividad. En efecto, el ya de por sí hermoso puente estaba adornado con arcos de palmas y flores, y la comitiva fue recibida con estampidos que parecían de cañón. Para ello, los obreros habían taladrado grandes rocas y llenado con pólvora los hoyos, para después hacerla explotar y provocar reverbera- ciones que rompían el inmemorial silencio de tan solitarios parajes.

Luego de cruzar el puente, el grupo subió la pendiente para llegar a la casa nacional o albergue, en la que ondeaba la bandera de Costa Rica y desde donde pudieron mirar el volcán Turrialba, enhiesto, majestuoso y en plena actividad. Es importante mencionar que sus erupciones de ceniza se iniciaron en setiembre de 1864, aunque desde 1853 emitía vapores (Tristán, 1922).

La comitiva pasó la noche en el albergue y el lunes al mediodía descendió hasta el puente, para el acto oficial de inauguración. "iQue este puente marque la era de un nuevo porvenir, de adelantamiento, de paz y de felicidad para el país, abriéndose el camino al Atlántico, y cambiando la faz de nuestra situación!" (Gaceta Oficial, 8 de abril de 1865, núm. 312, p. 4), sentenció el presidente Jiménez, de seguro evocando a los próceres Braulio Carrillo y Juanito Mora, los mayores impulsores de la anhelada ruta hacia el Caribe.

Nueve años después, al recorrer nuestro país a partir de Puerto Limón para recolectar plantas, el botánico alemán Otto Kuntze pasaría por Angostura y relataría: "después del desayuno pasamos el río Reventazón sobre un majestuoso puente de madera, y llegamos a un bosque espeso y llano, a través del cual pasaba un camino deplorable, que efectivamente no se podía pasar a pie" (Kuntze, 2001). Al año siguiente, su paisano y colega Helmuth Polakowsky, al llegar desde Turrialba y tras lamentarse del pésimo camino, narraría: "por fin éste se vuelve más sólido, desciende al valle del río Reventazón y salva este torrente por medio de un puente de piedra bueno, colocado en un sitio angosto, de unos $80 \mathrm{~m}$ (anchura de la superficie del agua en noviembre de 1875), que lleva el nombre de Angostura" (Polakowsky, 2014). Además de que esta anchura es exagerada -como se verá pronto-, en cuanto a su estructura de piedra tal vez quiso decir que el puente tenía bastiones de mampostería.

Para concluir lo referido a este puente, sorprende mucho que, aunque existe una foto tomada en Angostura por el alemán Otto Siemon cerca de 1873 -apenas un año antes de Kuntze- no aparezca el bello puente descrito por este. No obstante, en la parte izquierda de dicha imagen (figura 7) se observa parte de una estructura que podría corresponder al puente. 
Por cierto, en la parte superior de la foto se nota un rancho, en un sector desmontado, hoy profusamente cubierto con vegetación. Es de suponer que Siemon sí lo fotografió, pero que la imagen se extravió o está en alguna colección de difícil acceso en el extranje$\mathrm{ro}^{9}$.

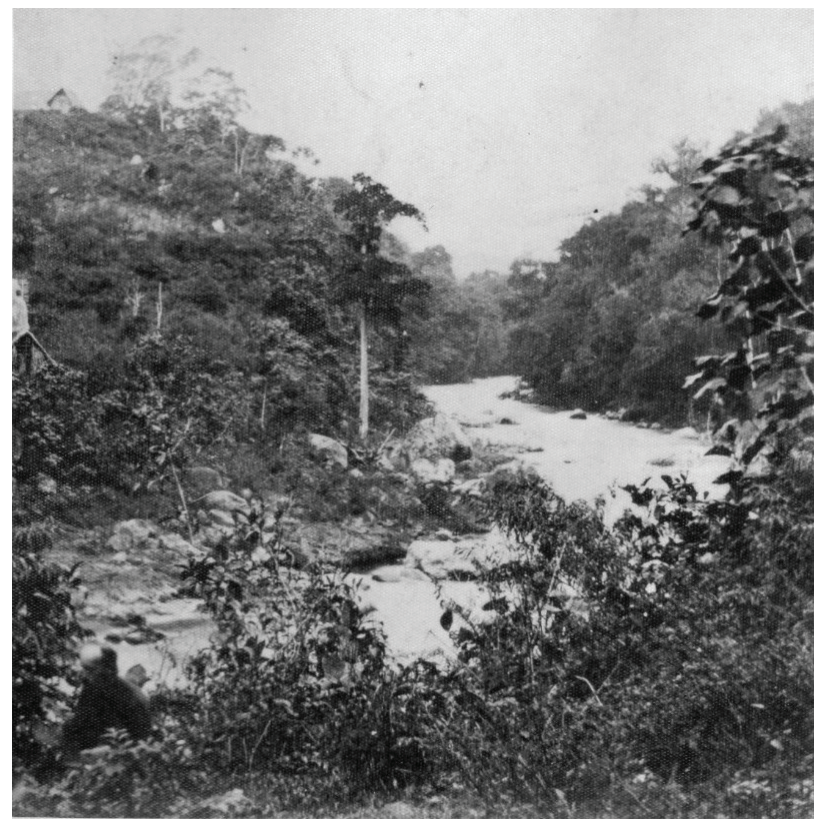

Figura 7. Vista de Angostura, cerca de 1873. Fuente: Otto Siemon

Es posible que el citado puente fuera bien conservado y permaneciera en su sitio por muchos años, aunque no los 30 o 35 años previstos por su constructor Francisco Kurtze, debido a la pluviosidad y alta humedad de la región. Al respecto, no ha sido posible hallar más testimonios escritos de este puente ni tampoco pictóricos, a pesar de que en años subsiguientes estuvieron por ahí varios viajeros. Visitantes alemanes como el obispo Bernardo Augusto Thiel (1882-1895), el geólogo Karl Sapper (1899) y el etnógrafo Walter Lehmann (1907-1908), así como los entomólogos estadounidenses Philip y Amelia Calvert (1910) ni siquiera se refirieron a él (entre paréntesis aparece la fecha en que cada uno de ellos estuvo ahî́). Incluso Lehmann y los esposos Calvert tomaron muchas fotos en esa zona, pero ninguna del puente. Asimismo, sorprende que el célebre fotógrafo estadounidense Harrison Nathaniel Rudd en 1893 adquirió una propiedad en Tuis, por lo que de seguro cruzó Angostura

$9 \quad$ Las fotos de Siemon aquí mostradas fueron cedidas por Silvia Meléndez, de la colección de su padre, el extinto historiador Carlos Meléndez Chaverri. varias veces. Sin embargo, en las colecciones de fotografías disponibles en Costa Rica y Estados Unidos (Universidad de Duke, en Carolina del Norte) no hay imágenes del puente y ni siquiera de Turrialba.

La posible explicación de esto es que para entonces el puente estaba tan deteriorado, que no llamaba la atención como para ser captado en una fotografía o ya ni siquiera existía. De esto da fe el hecho de que el $1^{\circ}$ de agosto de $1890-25$ años después de construido-, un grupo de agricultores ausentistas, residentes en Cartago y San José, enviaban una petición al gobernador de Cartago, fundamentada en que el puente estaba "tan deteriorado y ruinoso, que es constante el peligro de la vida, y de los ganados y frutos de los que poseen al otro lado del río algunas fincas" (Archivo Nacional de Costa Rica, 1890). Ellos eran Francisco Sancho, Dolores Gutiérrez (¿Guzmán?), Jenaro Bonilla Aguilar, Mariano Montealegre Gallegos, Francisco María Yglesias Llorente, Carlos Volio (¿Llorente?), el médico canadiense Tomás Mauricio Calnek Bogart, el cubano Antonio López-Calleja Pereira y el alemán Guillermo Steinvorth Ulex.

Argumentaban que, estimulados por la apertura de la carretera nacional, construida otrora hasta El Zapote -hoy Linda Vista-, algunos finqueros se establecieron en esa zona, pero que ahora esa ruta estaba en el abandono, por lo que resultaban perjudicados, sin poder tampoco llevar sus productos a algunos puntos de la línea ferroviaria, próxima a estrenarse. Asimismo, "no solo los particulares, sino también la Nación, están interesados en el buen estado de ese puente, puesto que, al otro lado del río posee aquélla grande extensión de terrenos baldíos, cuya fertilidad, planicie y extensión recomiendan las ventajas de dedicar protección a aquellos parajes" (Archivo Nacional de Costa Rica, 1890). Culminaban su petitoria solicitando que, con fondos públicos, se realizara "la reforma o conclusión del puente de Angostura, del cual subsisten en perfecto estado los bastiones". De esta frase final se capta que permanecían incólumes los bastiones hechos por Kurtze y que el puente como tal necesitaba una fuerte reparación o su renovación completa. Es de suponer que el puente fue reparado, a juzgar por el hecho de que en la documentación oficial disponible en el Archivo Nacional no hay nuevas referencias a puentes, al menos en el corto plazo. 


\section{LOS AVATARES DEL TERCER PUENTE}

Para comenzar, es oportuno resaltar la poca importancia asignada a los puentes por parte de los primeros autores de textos históricos sobre Turrialba, como Valerio (1953) y Salazar (1970), e incluso en las actas de la municipalidad de Turrialba. Dichos documentos - depositados hoy en el Archivo Nacional- para los fines de estas pesquisas comprenden un intervalo de 42 años, de 1920 a 1962, pero hay un vacío de unos 30 años, de 1890 a 1920.

En cuanto a Valerio (1953), todo cuanto consigna en alusión al que observara Polakowsky -ya mencionado-, es que "ese puente de la Angostura fue construido por Francisco Hurthy, con cal traída desde Ánimas, en la cuesta de Gracias a Dios, en el Camino Real [a Matina]", lo cual es cierto, como se vio previamente, excepto que el apellido correcto es Kurtze.

Por su parte, Salazar (1970) incluye unas pocas menciones. Por ejemplo, el 7 de julio de 1906, un corresponsal anónimo del diario La República informaba que "con auxilio del gobierno y bajo la dirección de don Juan Rafael Jiménez O., se está transformando la temible cuesta de Angostura en camino de coches", para culminar la noticia esperanzado en que "ya dejaremos de oír los lamentos, unas veces, blasfemias otras de los bueyes".

Asimismo, dos años después, con fecha 17 de marzo de 1908, el corresponsal relataba que "los puentes de Angostura y otros sobre el mismo camino de Tuis, que se encuentran en muy mal estado, se están refaccionando por parte del Municipio, que no descansa un momento en atender a lo más urgente". Por su parte, el 27 de diciembre de ese año, el corresponsal de El Noticiero expresaba que "el puente sobre el Reventazón en el punto llamado La Angostura, está en peligro y temen que se vaya". Además, dos días antes había informado que "el puente sobre el río Reventazón que se había sido falseado con el temporal pasado y estaba reparándose, se lo llevó el río". Pero este más bien era el puente del tren, en La Junta, Siquirres. Tal fue la tragedia que de los obreros que lo reparaban "10 murieron, varios están gravemente golpeados y 25 se llevó el río", debido a que "ese río creció 10 varas más de lo ordinario". Este percance aparece descrito en un libro oficial de la Northern Railway Company (Anónimo, 1953), en el que se in- dica que el puente original fue totalmente destruido por la inundación.

A partir de entonces, se dispone de muy poca información. Por ejemplo, en 1915 hubo una iniciativa de un grupo de agricultores de Bóveda, Carrizal, Cacao y Pacuare, "una zona que tiene [una] superficie [de] cerca de diez mil hectáreas de terreno, [...] con tierras fertilísimas y con bosques cuajados de madera de superior calidad", quienes se quejaban de la dificultad de llevar sus productos a Turrialba por "la Carretera de [Jesús] Jiménez", que estaba "en muy mal estado", por lo que se demoraba de cuatro a cinco horas a caballo y un día en carreta. Por tanto, solicitaron que más bien se levantara un puente entre Peralta y el túnel -que está poco después del río Colima- para poder sacarlos a la línea ferroviaria (Archivo Nacional de Costa Rica, 1915). Aunque el Congreso aprobó "el estudio, localización y construcción de un puente sobre el río Reventazón" en dicho punto -muy lejos de Angostura-, sujeto a la disponibilidad de fondos e incluso el presidente Alfredo González Flores, dio el ejecútese al proyecto, nunca se concretó.

En este caso, al no aludirse a ningún puente en Angostura, es de suponer que el problema radicaba en el deterioro de la carretera nacional y no del puente. Sin embargo, cuesta creer que el viejo puente erigido por Kurtze aún estuviera ahí. Al respecto, hay una pista interesante, pero que data de muchos años después. En efecto, se trata de una carta del agricultor catalán Esteban Tortós Solá, residente en el caserío de Murcia, en la cual indica que "el puente sobre el Reventazón, una obra muy buena construida durante la administración pasada de Don Ricardo Jiménez, se encuentra en un desastroso deterioro por falta de pintarlo; desde la época que se construyó (1912) nunca se ha reparado, por cuyo motivo [de] los goznes, o sea la parte de los tornillos, se levantan cascarones de herrumbre como de un grueso de $1 / 4$ de pulgada. ¡Figúrese el desgaste tan serio que está sufriendo el hierro!" (Archivo Nacional de Costa Rica, 1920-1929 y 20 de enero de 1926). A juzgar por dicha carta, hubo un puente nuevo, posterior al de Kurtze, aunque no fue posible hallar ninguna información al respecto.

No obstante, pareciera que Tortós se confundió con un puente inaugurado ahí en 1923, al que se aludirá en detalle pronto. Pero si lo mencionado por él fuera 
verídico, debe destacarse que esto sería muy meritorio, pues a Ricardo Jiménez Oreamuno -quien también tuvo propiedades en Turrialba- le correspondió asumir el poder apenas cuatro días después del muy destructivo terremoto del 4 de mayo de 1910 y las labores de reconstrucción fueron muy dispendiosas para el Estado, además de que se prolongaron por varios años. Cabe acotar que él era hijo de Jesús Jiménez Zamora y nieto de Francisco María Oreamuno Bonilla, otrora socios de la Sociedad Itineraria del Norte.

En todo caso, la siguiente información acerca de puentes data de 1920 y revela que el puente tendido en Angostura no recibía mantenimiento adecuado. En efecto, el 7 de julio de 1920, un inspector de la Dirección General de Obras Públicas, Miguel Molina M., indicó que al puente "lo que actualmente le hace falta son 28 tabloncillos de 0,30 de ancho por 0,05 de grueso y 3,25 de largo, y además habrá que templar unos cables que tiene a ambos lados y que hacen las veces de templaderas y están ayudando al puente, y como en vez de remaches tiene tornillos, creo que haya unos cuantos flojos, por lo que habría que socarlos" (Archivo Nacional de Costa Rica, 1920-1929). No se especifica si las medidas eran en varas o en metros, pues en el informe aparecen ambas escalas usadas indistintamente, aunque sí se capta que los tablones tenían un espesor de unos 5 $\mathrm{cm}$. Asimismo, Molina sugería que esta reparación se encargara al Jefe Político del lugar.

Curiosamente, en su informe Molina alude a otro puente, de 10,10 m de largo, colocado $20 \mathrm{~m}$ antes del primero, "sobre un zanjón hondo, donde el río cuando crece lo inunda, y por allí desagua una quebrada". Advierte que desde que se construyó estaba apoyado apenas cuatro pulgadas sobre cada bastión, cuando lo recomendable era al menos 12 pulgadas en cada extremo. Para impedir su desplome en caso de una contracción de los bastiones, sugería que "eso podría evitarse apuntalándolo en los extremos con vigas de hierro o rieles, en forma de pie de amigo". Por la descripción, pareciera que este puente era el colocado entre la ribera izquierda del río y la roca que había en medio, pero los 20 m de distancia parecen exagerados. En cuanto a la citada quebrada, no existe hoy, aunque cabe pensar que más bien era un pequeño curso de agua que desapareció cuando se construyó el actual puente y la carretera que desciende hacia él fue pavimentada.

Pocos días después, su jefe, M.E. Vázquez, tramitó esta gestión ante el Secretario de Fomento, Narciso Blanco Mora, pero no hay documentación que permita verificar si se hizo la reparación. Al parecer no o se hizo de manera incompleta, pues ya en enero de 1921, en respuesta a un telegrama del Jefe Político de Turrialba, se comunicaba al Director General de Obras Públicas que "Mr. Herzog y otros importantes vecinos de aquella región me informan que el puente sobre el río Reventazón (Paso de Angostura) camino a Tuis, amenaza ruina. Ruégole a $U$. enviar un ingeniero para reconocer el estado del puente". Es pertinente indicar que el suizo Rodolfo Herzog Müller se había instalado en Turrialba como administrador de la hacienda Atirro Coffee States, propiedad del estadounidense Charles Woodman, quien heredó esos predios a su hija Carlota, que se casó con Herzog.

Como complemento de estos datos, fue poco después -en marzo de 1921- que la municipalidad de Turrialba solicitó a Herzog "una lista detallada de los contribuyentes voluntarios y cantidades para el arreglo del camino de Tuis, para así resolver la suma que esta Municipalidad puede asignar" (Archivo Nacional de Costa Rica, 20 de marzo de 1921). Es de suponer que se refería al trecho del camino desde el puente de Angostura hasta Tuis, que cortaba la hacienda La Suiza. Conviene indicar que en agosto del año anterior, Herzog había donado el terreno para la apertura de calles en La Suiza, por lo que entregó las respectivas escrituras a la municipalidad.

A pesar de estas preocupaciones y propuestas, todavía en noviembre de 1921 el puente no estaba reparado. De hecho, en esos días Vázquez envió una carta a Blanco, en la que expresaba su desacuerdo con una petición de Herzog y otros empresarios, en el sentido de que se eximiera del pago de impuestos por los materiales necesarios para la reparación (Archivo Nacional de Costa Rica, 4 de noviembre de 1921). No obstante, accedería "salvo que se comprometieren a permitir el libre uso del puente para el público", lo cual de manera implícita revela que a esta estructura se le daba un uso privado, en beneficio exclusivo suyo y quizás de algunos otros hacendados de la zona. Este asunto se retomará pronto. 


\section{POR FIN, UN PUENTE DE METAL}

Las evidencias sugieren que -como es frecuente en nuestro país, por diversos motivos- todo cuanto se hizo por muchos años fue efectuar reparaciones de menor cuantía o remiendos que, al final de cuentas, no resolvían el problema de fondo. Asimismo, nótese que habían trascurrido dos años sin que se hiciera mayor cosa con el puente en Angostura. Y aunque con el tiempo la situación se agravó aún más, también surgió una firme esperanza. En efecto, en febrero de 1922 se argumentaba que "el puente de Angostura se encuentra en completo mal estado, y en atención a que en la Dirección General de Obras Públicas se está haciendo un puente de hierro para dicho paso, razón por la cual esta Municipalidad no estima conveniente hacer ninguna reparación sobre dicho puente". Ante esta loable iniciativa, de instalar un puente nuevo y muy firme-cuyos gestores locales y gubernamentales se desconocen-, dicho ente acordó "dirigirse a la Dirección General de Obras Públicas por medio del señor Gobernador, a fin de que manifieste cuándo estará listo el puente, deseando este Ayuntamiento que se active ese trabajo, por ser de perentoria necesidad" (Archivo Nacional de Costa Rica, 22 de febrero de 1922).

No fue posible determinar si hubo alguna respuesta oficial. Lo cierto es que el panorama no cambió y seis meses después la municipalidad acordaba "pasar atenta comunicación a la Dirección General de Obras Públicas, indicándole que esta Municipalidad ha tenido noticia de que el puente que allí se construye para el paso de La Angostura sobre el Reventazón, no se ha terminado por falta de recursos. Que se digne manifestar a esta Corporación, qué cantidad hace falta para su pronta terminación, para ver si es posible que el Municipio pueda contribuir siquiera en parte, a fin de que sea terminado cuanto antes sea posible" (Archivo Nacional de Costa Rica, 9 de agosto de 1922).

Es posible que ahora sí hubiera una respuesta, que no fue posible hallar, o tal vez una llamada telefónica oficial, pues la solución empezó a tomar forma, finalmente. Dos semanas después, por instrucciones de los regidores, el Jefe Político, Ricardo Fernández B., envió una carta al Gobernador de Cartago, Francisco Jiménez Oreamuno -quien compartía apellidos, pero no era hermano de Ricardo-, en la que expre- saba que el puente de Angostura "está en estado de completa ruina, y según dictamen técnico, amenaza caerse de un momento a otro". Y tan deteriorado estaba, "que precisa reponerlo a la mayor brevedad para evitar una catástrofe, y el posible aislamiento de los distritos de Tuis y Atirro, lo cual impediría movilizar la próxima cosecha de café de esa región" (Archivo Nacional de Costa Rica, 23 de agosto de 1922).

Cabe hacer una digresión aquí para señalar que no se cuenta con una descripción que permita conocer si el deteriorado puente era de madera o metal. No obstante, de dicha carta se colige que si ese puente fue erigido en 1912 -en la administración Jiménez Oreamuno-, es impensable que fuera una estructura de metal y que se hubiera arruinado en apenas 10 años. Por tanto, es de suponer que era de madera.

Para retornar al acuerdo municipal de fines de agosto, en él se reconoce y explicita que "estaba agotada la partida del Presupuesto Nacional votada para la construcción de puentes", lo cual era lo que impedía concluir la estructura. Sin embargo, a su vez aclaraba que aunque "la cantidad necesaria es relativamente pequeña", no era sencillo sufragarla, pues "esta corporación no puede distraer fondos municipales para dicho fin, por ser el puente de Angostura un puente nacional". Eso sí, en dicho acuerdo al final se advertía que "la Corporación, al hacer esta excitativa, declina toda clase de responsabilidades que puedan sobrevenir por motivo de una catástrofe, ya por las pérdidas materiales, o ya por las pérdidas de vidas" (Archivo Nacional de Costa Rica, 23 de agosto de 1922).

Es importante reconocer que, ante esta carencia de fondos, en el citado acuerdo y en correspondencia referida al caso, consta que los empresarios Cecil y Stanley Lindo Morales, Miguel Monge Jiménez y Federico Pérez Rubín "generosamente ofrecieron contribuir con fuertes sumas para dicho fin", a la vez que los munícipes lamentaban "la negativa absoluta de don Rodolfo Herzog" de contribuir. Cabe indicar que los hermanos Lindo eran jamaiquinos de padre inglés, en tanto que Pérez era español. Al respecto, sorprende mucho la actitud de Herzog pues -irónicamente- era uno de los que más se había quejado del estado del puente, como se indicó en páginas previas. Pero, además-como ya se vio-desde el año anterior se le había manifestado que la exención de 
impuestos por los materiales para reparar el puente dependería de que él permitiera que lo utilizara la gente.

Y aunque hubiera sido de esperar que cambiara su posición, esta más bien se exacerbó, por lo que en marzo de 1922 la municipalidad debió reconvenirlo. En tal sentido, los munícipes destacaban que: "Oído el informe del Sr. Jefe Político, respecto a la gestión con don Rodolfo Herzog, tendiente a que volviera a establecer el tráfico quitado por él por medio de un portón con llave en el camino de Atirro, alegando que dicho camino es parte de su finca, y que él responde por cualquier reclamo, se acuerda: Manifestarle al Señor Herzog que en el archivo de esta Municipalidad existe copia de un convenio con los anteriores dueños de esas fincas, por el cual consta que el camino a que se hace referencia es público, de lo que se le adjunta una copia, y en virtud de eso, se le conceden ocho días de término para que proceda a abrir el camino y de lo contrario, se hará por medio de la autoridad respectiva" (Archivo Nacional de Costa Rica, 8 de marzo de 1922).

Este texto sugiere que su hacienda empezaba en el actual cruce hacia La Suiza, después de subir la cuesta que se inicia en la ribera derecha del río Reventazón. Es decir, no se contaba con un camino público ni tampoco con una servidumbre para poder transitar desde Turrialba hasta Tuis.

La terquedad de Herzog fue tal, que dos meses después la situación persistía. Y en lugar de actuar con mano firme, la municipalidad le dio otra prórroga, tan laxa que fue "de ocho o quince días". Pero una vez más, él ignoró la advertencia y para diciembre las cosas permanecían igual. Entonces, de nuevo, se le otorgó un plazo "de ocho días para que restituya el camino a su estado primitivo" y transcurrido este intervalo, "el señor Jefe Político dará los pasos necesarios para que dicho camino quede abierto definitivamente al servicio público". Es de suponer que por fin el asunto se resolvió, a juzgar por el hecho de que tres meses después Herzog intentó "poner peones a trabajar en el camino de Tuis" -obviamente, con fondos públicos-, ante lo cual se le indicó que la municipalidad carecía de fondos en este rubro (Archivo Nacional de Costa Rica, 24 de mayo, 27 de diciembre de 1922, y 14 de febrero de 1923).
Para retornar a la cuestión del puente, se ignora si finalmente Monge, Pérez y los hermanos Lindo hicieron aportes económicos para su construcción; al parecer, no hubo necesidad. Como la Dirección General de Obras Públicas informó a la municipalidad que el monto necesario correspondía a $\$ 3.999,14$ una cifra más bien modesta, dada la magnitud de esa obra- bastaba con optar por una vía administrativa. Y fue así como se solicitó al gobernador provincial Jiménez que persuadiera al Secretario de Gobernación -Aquiles Acosta García, hermano del presidente-, para que se incluyera el caso en las sesiones extraordinarias del Congreso, las cuales recién se habían iniciado. Al parecer, Jiménez no lo hizo con la urgencia deseada, lo que ameritó un nuevo acuerdo municipal (Archivo Nacional de Costa Rica, 13 de setiembre de 1922). Por fortuna, la petición municipal fue atendida con relativa prontitud y eficiencia por todos los involucrados y, tras la aprobación de la solicitud por parte del Congreso, el 18 de octubre recibía el ejecútese del presidente Julio Acosta.

Conviene hacer una digresión para señalar que Acosta tenía cierta afinidad con Turrialba, pues él fue uno de los líderes de la denominada Revolución de Sapoá, contra la dictadura de los hermanos Joaquín y Federico Tinoco. Y, como parte de las luchas por la democracia ocurridas en varios puntos del país, en febrero de 1918 hubo un enfrentamiento con el ejército tinoquista en la hacienda Guayabo, en Turrialba, organizada por Mariano Guardia Carazo, Juan Gómez Álvarez, Federico Pérez Rubín y Aurelio LópezCalleja Basulto (Monge, 1976).

Como culminación de los bien conducidos esfuerzos de la municipalidad de Turrialba, la muy esperada resolución final del Congreso rezaba así: "Amplíase la partida correspondiente del presupuesto de Fomento del presente año con la suma de cuatro mil colones $(\$ 4.000 .00)$ que se destinarán a terminar y colocar el nuevo puente llamado de Angostura sobre el Río Reventazón en el camino de Tuis" (Archivo Nacional de Costa Rica, 1922). Es pertinente aclarar que por entonces Tuis era el segundo distrito de Turrialba, pero fue desplazado por La Suiza, que inicialmente era tan solo una finca o hacienda en el valle de Tuis y después se desarrolló mucho, sobre todo gracias a Herzog. Dicha finca fue fundada por sus paisanos 
Adriano Dormond Oguey, Luis Peytrequín Pfister y Alfredo Dotti Pitet.

Aprobados los fondos y concluida la estructura en los meses subsiguientes, la municipalidad fue informada al respecto, por lo que hacia fines de mayo de 1923 acordó nombrar una comisión, constituida por su presidente Mariano R. Montealegre Carazo y el Jefe Político Fernández, para "que en nombre de este Ayuntamiento inviten al Señor Presidente de la República y su gabinete, para la inauguración del trabajo del ramal de ferrocarril al Pejivalle y el puente de la Angostura", además de autorizar que se les hiciera un agasajo (Archivo Nacional de Costa Rica, 23 de mayo de 1923).

Nótese que se deseaba aprovechar la visita del presidente de la República para -de manera simbólicacolocar el primer clavo del primer riel de dicho ramal; al respecto, debe recordarse que el ferrocarril al Caribe había empezado en diciembre de 1890.

Sin embargo, esto no fue del todo sencillo, a pesar de ser una obra de gran importancia, ya que Pejibaye era una nueva y pujante zona bananera. Así lo había acordado la municipalidad en noviembre de 1922, por lo que solicitó el aval del Ministerio de Fomento e hizo los trámites pertinentes con las empresas involucradas en el proyecto (Archivo Nacional de Costa Rica, 16 de noviembre de 1922). Aunque no se mencionan sus nombres, es evidente que se trataba de la empresa ferroviaria Northern Railway Company y la empresa bananera United Fruit Company. No obstante, cuando nadie lo esperaba, surgió la oposición del alemán Guillermo Niehaus, dueño de la hacienda Aragón, la cual sería atravesada por la línea férrea e incluso se beneficiaría con el proyecto. Esto obligó a los regidores a solicitar al gobierno que se expropiara la faja de terreno necesaria, dado que le ley lo permitía, por ser un proyecto de gran relevancia local y nacional (Archivo Nacional de Costa Rica, 22 de febrero de 1923).

Para retornar la cuestión del puente, Ilama la atención que en las actas de la municipalidad no se mencione la fecha de su inauguración, y después del acuerdo anterior no se vuelve a hacer alusiones al puente. Sin embargo, la búsqueda en la prensa aportó un dato clave. Con el título Don Julio en Turrialba, una breve noticia en el Diario del Comercio revelaba que ello ocurriría el domingo 3 de junio, en medio de feste- jos cívicos, y que "en Turrialba hay mucho entusiasmo por la inauguración del puente de la Angostura" (Diario del Comercio, 31 de mayo de 1923).

Otro medio periodístico, La Tribuna, anunció el evento el propio domingo, con el título Inauguración de un puente en Turrialba y la breve noticia era ilustrada con una foto del puente completo, montado en la plataforma de un carro del tren, antes de ser transportado tiempo atrás. Su construcción estuvo a cargo del ingeniero Fernando Cabezas, cuyo jefe era Manuel Antillón Ramírez. En ella se indica que la comitiva oficial saldría ese día a las siete de la mañana, por tren, para regresar el mismo día a las cuatro de la tarde. Asimismo, en medio de otros elementos, aclaraba que ese viaje se había pospuesto varias veces "porque se necesitaba llenar algunos detalles preliminares", lo cual sugiere que la estructura estuvo lista mucho antes (La Tribuna, 3 de junio de 1923).

Como una curiosidad, relacionada de manera indirecta con Turrialba, en los días previos a la inauguración del puente en Angostura la prensa anunciaba que "se encuentra en esta capital el Rey de los Indios de Talamanca, S.M. Tipisín $1^{\circ}$, amo de la zona del Telire. Viene su real Alteza acompañado de sus esposas y sus hijas, perros, monos y pericos. La Real familia hizo el viaje a pie hasta Turrialba, y el Soberano le trae de obsequio al Presidente de la República una piel de tigre. Se hospedan en el Palacio Arzobispal" (Diario del Comercio, 27 de mayo de 1923).

Para regresar a la ceremonia de inauguración del puente, dos días después el diario La Tribuna le dedicó casi una plana al evento, con el título Las inauguraciones de Turrialba, ilustrada con fotografías de la comitiva llegando al puente, de la colocación del primer clavo de la línea a Pejibaye y del banquete ofrecido posteriormente. Además, en esa misma fecha el Diario del Comercio publicó una noticia amplia, aunque más modesta que la anterior, pero con elementos no citados en el otro periódico. Así, gracias a ambas crónicas, es posible reconstruir lo ocurrido en ese fastuoso día para Turrialba (La Tribuna, 5 de junio de 1923 y Diario del Comercio, 5 de junio de 1923).

En efecto, un tren expreso partió de la capital con la comitiva presidencial, de más de 20 personas, entre quienes figuraban algunos miembros del gabinete, invitados especiales y periodistas, etc. Del gabinete iban el ya citado Narciso Blanco -por cierto, hijo del 
general Máximo Blanco Rodríguez, controvertido héroe de la Campaña Nacional contra los filibusteros-, el notable educador Miguel Obregón Lizano y el médico Solón Núñez Frutos, más el coronel Manuel Luján; en Cartago se les sumaría el gobernador Francisco Jiménez Oreamuno. Cabe destacar que el presidente Acosta y el ministro Blanco vestían impecables trajes blancos y corbata oscura, así como elegantes botas altas de tubo; el resto de la comitiva usaba traje oscuro y corbata, así como botas, botines o botines con polainas.

En medio de gran expectación, el tren arribó a la estación ferroviaria cerca de las nueve de la mañana. Al descender la comitiva presidencial y ser recibida por la Corporación Municipal, se entonaron los acordes del Himno Nacional -a cargo de la Banda Municipal de Cartago y la filarmónica local-, el cual fue cantado al unísono por los ahí congregados. De inmediato se escucharon los nutridos aplausos de la multitud, entre la que sobresalían numerosas cabezas masculinas cubiertas con los elegantes y frescos sombreros panamá -que, en realidad, son de origen ecuatoriano- y a los aplausos siguieron abundantes vivas al presidente, a la municipalidad y a Turrialba.

Poco después el grupo se enrumbaba hacia la sede de la Jefatura Política, donde estaban ensilladas las cabalgaduras, para dirigirse hacia Angostura. Calculada la distancia en una hora, para llegar al puente el séquito fue acompañado por unos 50 lugareños. Ya en el sitio, los miembros del grupo encabezado por el presidente Acosta -quien iba flanqueado por dos militares que hicieron el saludo de rigor-, sin bajarse de sus caballos, los civiles se despojaron de sus sombreros para escuchar las notas del Himno Nacional con veneración; así consta en el pie de una de las fotos (figura $8 \mathrm{~A}$ ), escrito por quien la tomó ${ }^{10}$. Nótese en dicha foto que antes del puente principal había un puente corto, que permitía el acceso a él desde la ribera izquierda del río Reventazón.

10 De los actos de ese día se cuenta con 13 impecables imágenes, captadas por el célebre Manuel Gómez Miralles, quien fungía como fotógrafo oficial del gobierno. Hoy están en poder de don Julio Ernesto Revollo Acosta, nieto de don Julio Acosta.
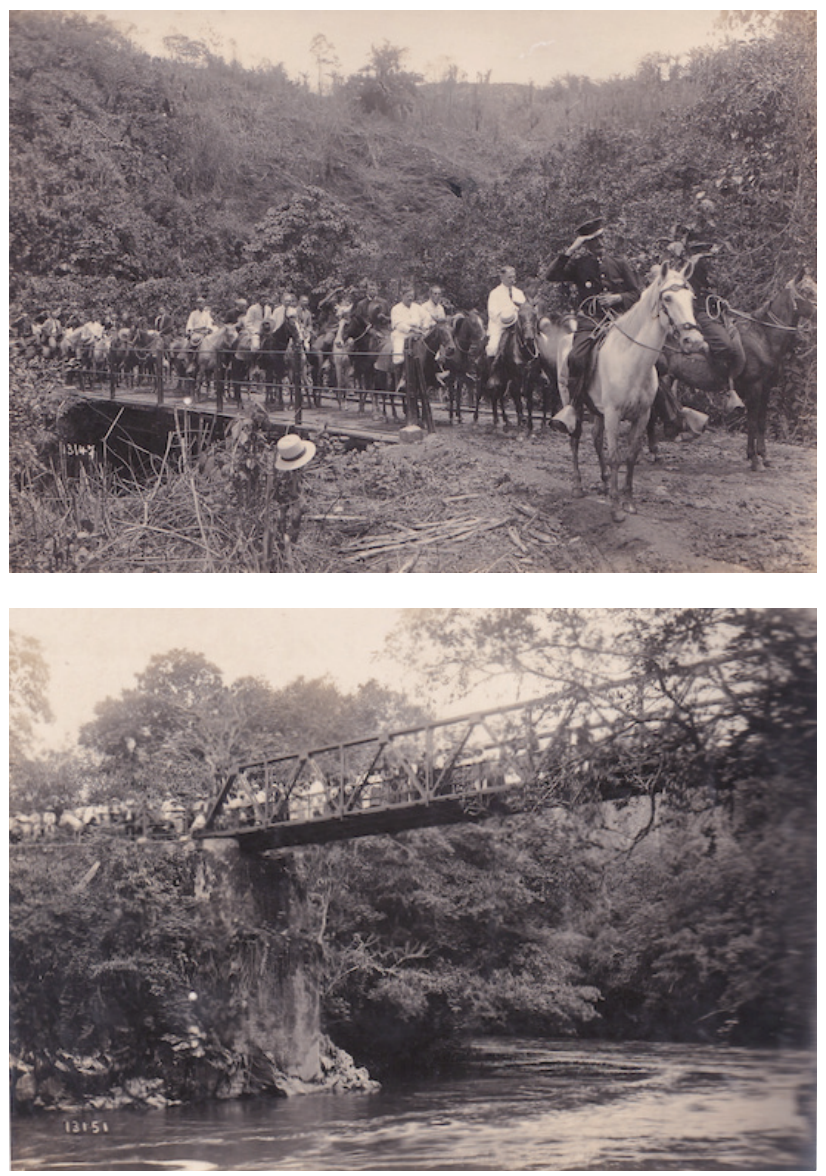

Figura 8. Llegada de la comitiva a Angostura, encabezada por el presidente Acosta (de blanco) (A), así como parte de la concurrencia ya sobre el nuevo puente (B). En B, nótese la inmensa roca sobre la que se levantó el bastión central. Fuente: Manuel Gómez Miralles

Después de esto, en una ceremonia más bien rápida y en la que se quebró una botella de champán contra la cercha del puente, el sacerdote alemán Santiago Bellut procedió a su bendición. En el acto fungieron como padrinos el presidente y la señora Amalia Brunetti de Blanco, esposa del Secretario de Fomento; al parecer, también lo fue la señora Sara Aguilar de Montealegre, esposa del presidente municipal, quienes habían venido con la comitiva presidencial.

Por cierto, según una de las noticias, la estructura medía 40 varas $(33 \mathrm{~m})$ de largo y se elevaba 25 varas $(21 \mathrm{~m})$ sobre el nivel del agua. Pero esto es algo exagerado, pues el construido por Kurtze medía unos 21 m de longitud y, además, en el boceto de un puente para exactamente el mismo sitio -trazado en 1942, al cual se aludirá después- consta que medía unos $25 \mathrm{~m}$, pero reposaba unos $2 \mathrm{~m}$ sobre cada uno de los bastiones. En todo caso, medidas más, 
medidas menos, lo cierto es que por fin se contaba con un sobrio y macizo puente de hierro en ese sitio, tan impregnado de historia, y que los asistentes al acto cruzaron jubilosos por primera vez (figura 8B).

A continuación todo el grupo se encaminó hacia Turrialba, donde el presidente insertó el primer clavo del primer riel de la línea que comunicaría la estación con Pejibaye, el cual fue celebrado con copiosos aplausos y vítores. Ahí participó Adolfo A. Osborne, como representante de la United Fruit Company, quien había venido con la comitiva. Al observar las fotos de esta ceremonia, se nota que en la intersección del ramal ya estaban asentados los durmientes y había un largo riel extendido sobre ellos. Esto ocurrió en las afueras de la estación ferroviaria, muy cerca de un pequeño puente metálico sobre el río Colorado que, por entonces, no había sido entubado; incrustados en el asfalto de la carretera, hoy ahí se observan los rieles del antiguo ramal.

Concluido este acto, que fue muy breve, al ser el mediodía la comitiva y algunos notables lugareños caminaron unas pocas cuadras para reunirse y almorzar en el Nuevo Hotel Roma, en las proximidades de la estación ferroviaria. Este negocio -perteneciente a Lorenzo Chacón y Cía.- estaba en un bello edificio de madera con un amplio balcón en el segundo piso. Para la ocasión, estaba adornado con cintas con los colores de la bandera patria, así como guirnaldas de flores. Amenizado con "preciosas y delicadas piezas musicales" ejecutadas por la Banda Municipal de Cartago y la filarmónica local, se sirvió un opíparo almuerzo, que constaba de 14 ítems, entre aperitivos o entremeses, ensaladas, platos fuertes y postres. Como una curiosidad, el menú estaba escrito en francés y hasta los humildes, pero sabrosos, peces bobos del Reventazón terminaron no solo asados, sino también... afrancesados, pues en el menú se les describe como Bobos d'Angostura grillés.

Posteriormente hizo uso de la palabra Jorge R. Aguilar Morúa -a nombre de la municipalidad, pues parece que era su abogado- para ofrecer el almuerzo al presidente Acosta y agradecer su gran interés por la zona de Turrialba, lo cual fue seguido por "una salva de aplausos", que culminó con un brindis con champán.

A continuación tomó la palabra el presidente. En su discurso "se refirió a las obras inauguradas extensa- mente" y resaltó la importancia de invertir en obras públicas "que convierten a regiones infecundas en verdaderos emporios de riqueza y de progreso material". Sin embargo, la nota periodística de La Tribuna (5 de junio de 1923) no aporta detalles al respecto, sino que se concentra en transcribir grandes párrafos de una amplia reflexión de carácter más bien político-electoral y retórico, propio de la coyuntura, pues ya había agitación, a pocos meses de las elecciones. Por cierto, los candidatos serían Ricardo Jiménez Oreamuno (Partido Republicano), Alberto Echandi Montero (Partido Agrícola) y Jorge Volio Jiménez (Partido Reformista); como ninguno alcanzó el 50\% de los votos, el congreso eligió al primero (Obregón, 2002). Saludado el discurso con "una atronadora salva de aplausos", el presidente alabó las obras inauguradas ese día y a quienes las hicieron posibles.

Cabe hacer una digresión aquí para destacar -tal vez él lo hizo en el discurso- que para el presidente el puente en Angostura tenía un significado particular. Y quizás eso también contribuyó a que, gracias a las respectivas condiciones de presidente y de ministro, de él y de su hermano Aquiles, fue que en meses previos el gobierno adoptó la positiva y rápida decisión de erigir el puente.

Nacidos en San Ramón (Alajuela), eran sobrinos de Domitila Acosta Chaves, casada con Carl von Bülow Bronikowsky, sobrino a su vez del célebre barón von Bülow, el primer residente en la fallida colonia alemana de Angostura. Asimismo -como se vio en páginas previas- fue el alemán Eduardo Steffen quien construyó el bello puente diseñado por Kurtze. Él residiría en San Ramón, donde vivía su hermana Guillermina, casada con Agustín Piepper, uno de los colonos de Angostura, cuya hija Adelina Piepper Steffen se casó con Paulino Acosta Chaves, tío del presidente. En síntesis, Julio y Aquiles tenían primos hermanos que eran medio alemanes - de apellidos von Bülow Acosta y Acosta Piepper-, de ancestros asociados con Angostura.

Ahora bien, para retornar a los actos de ese día, concluida la intervención presidencial, habló el ingeniero Cabezas -quien se refirió a unas 40 obras públicas del gobierno a punto de concretarse-, así como Salvador Villar, al parecer como representante de los vecinos. Posteriormente se hizo un recorrido por la ciudad, que incluyó sendas visitas a la escuela 
y la iglesia, "que son dos obras también de adelanto, que exponen claramente el espíritu progresista de la ciudad", según una de las notas periodísticas de La Tribuna (5 de junio de 1923). Por lo visto, no hubo Iluvia por fortuna, lo cual es algo casi insólito en este cantón, al punto de que los lugareños lo denominan Lluvialba. A las cuatro de la tarde la comitiva presidencial abordó el tren expreso y después de atravesar bosques y predios cultivados, y también el magnífico puente ferroviario sobre el río Birrís, llegó a la capital cerca de las siete de la noche.

Cumplida la jornada, ahí permanecería por muchos años esa excelente y sólida obra de ingeniería. Si Kurtze había previsto que el puente de madera que él construyó duraría 30-35 años, es de esperar que el de metal estuviera en ese sitio quizás medio siglo. El único inconveniente era que podía ser cruzado por apenas una carreta a la vez, debido a su estrechez. Aunque ya desde 1910 circulaban automóviles en algunas partes del país -los célebres Ford T o fotingos-, los fragosos caminos de esos parajes no permitían su tránsito en aquel entonces.

No se ha hallado más noticias acerca de este puente. Como ya se indicó, no se sabe si era a este o a un supuesto puente de 1912 al que a inicios de 1926 se refería el agricultor español Tortós, acerca de su deterioro por falta de pintura. Lo cierto es que por esos mismos días hubo un acuerdo de la municipalidad de Turrialba, en el sentido de "autorizar al Jefe Político, para mandar poner unos tabloncillos que necesita con urgencia el puente de Angostura, con cargo a Calles y Puentes de Tuis", o sea, en un rubro correspondiente al presupuesto de este distrito (Archivo Nacional de Costa Rica, 13 de enero de 1926). Es decir, la estructura de metal estaba incólume, pero demandaba un mantenimiento periódico, así como reparaciones de menor cuantía.

En tal sentido, llama mucho la atención la existencia en el Archivo Nacional de un detallado croquis, que data del 12 de mayo de 1942 -en el gobierno de Rafael Ángel Calderón Guardia- y se intitula Plano general y perfil de los puentes sobre el río Reventazón en La Angostura de Turrialba, en la carretera Turrialba-Chitaría (Archivo Nacional de Costa Rica, 1942). Fue elaborado por Juan J. Harley Q. como auxiliar de ingeniería de puentes y refrendado por el Director General de Caminos y Puentes. Aunque la firma de este no es del todo legible, podría corresponder a la de Federico Gutiérrez Braun -nieto del alemán Juan Braun Roesler-, quien para 1940 ocupaba ese puesto. Este documento, trazado en papel y que mide $94 \times 60 \mathrm{~cm}$, es de gran valor informativo no solo por los cinco esquemas que contiene, sino también por las detalladas medidas de la estructura. Los esquemas corresponden a un plano general o vista aérea (a escala 1:200, es decir, $1 \mathrm{~cm}$ en el papel equivale a $200 \mathrm{~cm}$ o $2 \mathrm{~m}$, en la realidad), así como a dibujos de la estructura, que consistía en un puente corto y otro largo, de los cuales hay vistas longitudinales y transversales, a escalas más detalladas, de 1:100 y 1:50, respectivamente.

En el plano general (figura 9A) se observa que la inmensa roca del cauce está flanqueada por cuatro "cortinas" o paredes gruesas y posiblemente esa sección se rellenaría con piedra y cemento para construir una especie de plataforma, de modo que los vehículos y la gente pudieran transitar y que a la vez sirviera de bastión para cada uno de los puentes, asentados en los respectivos bastiones de ambas riberas, nuevos y amplios. En cuanto a estos, eran de diferente aspecto, pues solo el pequeño tenía barandas simples, de $1 \mathrm{~m}$ de altura, en tanto que el grande tenía dos cerchas (figura 9B) de 2,3 m de altura. Sus respectivas dimensiones eran 12,20 $\mathrm{m}$ (largo) y 2,70 m (ancho), así como 24,25 m (largo) y 3,5 m (ancho). Nótese que el pequeño era más angosto. Además, se alzaban 8,40 m y 10 m desde el nivel del agua, respectivamente.

En realidad, este puente se parece mucho -o es idéntico- al construido en el gobierno de Acosta. Además, el citado croquis no está acompañado por documentación alguna y en el Archivo Nacional tampoco hay ninguna otra referencia sobre él. Ante la duda, la revisión de las actas municipales revela que nunca hubo una gestión para construir un puente en Angostura, aunque hay menciones de caminos y puentes en diferentes épocas, incluso en las cercanías de Angostura. Dicha revisión comprendió ocho años (1941-1949), dado que acontecimientos como la Primera Guerra Mundial (1939-1945) y la Guerra Civil de 1948 podrían haber dificultado o impedido la concreción de la obra. 
Revista Comunicación. Volumen 26, año 38, núm. 2, julio - diciembre, 2017 (pp. 93-127)
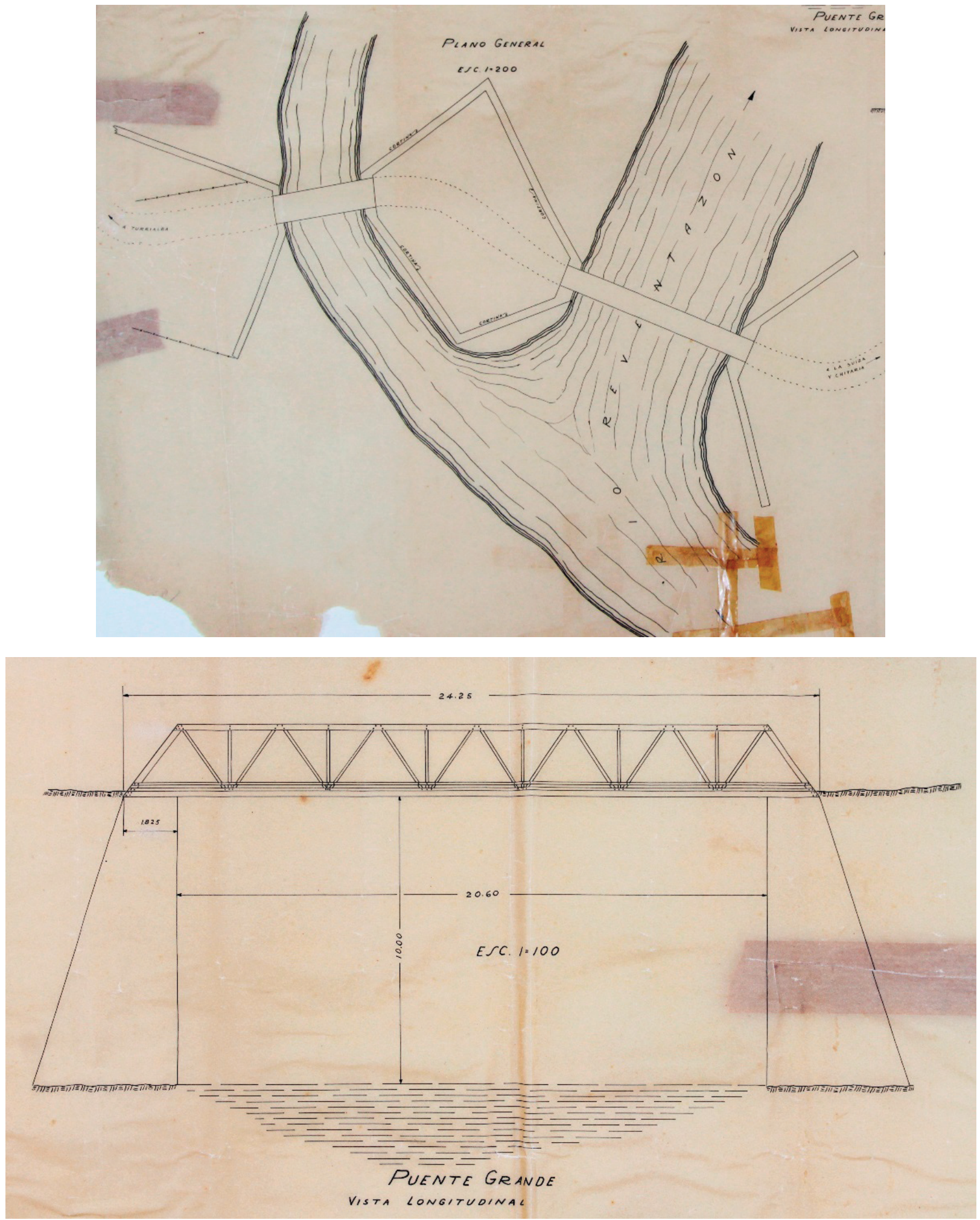

Figura 9. Plano general de la ubicación de ambos puentes en el punto de Angostura (A), así como las características del puente grande (B). Fuente: Archivo Nacional 
No obstante, tan ignorado fue el puente -lo cual sugiere que estaba en buen estado-que, por ejemplo, a inicios de 1943 los munícipes solicitaron a la Junta Cantonal de Caminos "reparar la pendiente llamada de Angostura", pues, "a decir verdad, eso representa una contribución al mantenimiento vital que tanto necesita la agricultura, principalmente la caña en estos momentos" (Archivo Nacional de Costa Rica, 10 de enero de 1943). Es decir, se menciona la escarpada pendiente que desciende desde el actual CATIE, pero no se alude al puente.

Asimismo, tres años después, a fines de 1946, concurrieron a una sesión municipal extraordinaria, Claudio Escoto León, Subsecretario de Fomento, con Renán Méndez, Gonzalo Lizano y Federico Lowsse, jefes de puentes, carreteras y conservación de carreteras, respectivamente. Hubo una amplia discusión acerca de la construcción de una buena carretera entre Juan Viñas y Turrialba, para lo cual se emitirían 436 bonos de 1.000 colones (Archivo Nacional de Costa Rica, 28 de noviembre de 1946). En ese intercambio de ideas -el acta consta nada menos que de 13 páginas- se mencionaron otros puentes y caminos, incluyendo "la carretera Instituto-Platanillo, en una excelente zona cañera". Puesto que el citado ente era el Instituto Interamericano de Ciencias Agrícolas (IICA) y Platanillo está después de La Suiza, esa ruta debía atravesar el puente de Angostura.

Dada la laboriosidad de revisar las actas, se detuvieron las pesquisas cuando se detectó que, unos dos años después -a inicios de marzo de 1949-se acordó "dirigirse al MOP, comunicándole acerca del mal estado en que se encuentran los tabloncillos del Puente de La Angostura sobre el Río Reventazón, solicitándole sea muy servido ordenar el arreglo, para evitar el peligro que hay en el paso de ese puente" (Archivo Nacional de Costa Rica, 2 de marzo de 1949). Es decir, es evidente que -con apenas 25 años de uso- la estructura de metal estaba en buenas condiciones, por lo que no tenía sentido levantar una nueva.

Todos estos indicios conducen a la hipótesis de que el croquis ya citado se hizo más bien como un anteproyecto para el reforzamiento del bastión central y los de ambas márgenes, mediante las citadas "cortinas" y así evitar su erosión por las corrientes del río. Es posible que esos trabajos no se efectuaran, a juzgar por el hecho de que el aspecto de los bastiones actuales no coincide con el del croquis.
Para concluir, es interesante mencionar una información aparecida en la prensa, pero de fecha desconocida, lamentablemente. En efecto, ahí se observan dos fotos del puente (figura 10A-B), calzadas con la siguiente leyenda: "Soberbia vista panorámica del paso llamado de "La Angostura", en el río Reventazón, carretera "Jesús Jiménez", al sur de Turrialba. Esta obra la forman dos pequeños puentes de poco costo, que se apoyan y son sostenidos a gran altura por una isla de roca natural que hay en el centro del río. Puentes costosísimos construidos en otros lugares sobre el mismo río por el gobierno, la compañía [¿ferroviaria o bananera?] o particulares, fueron arrastrados o destruidos por las fuertes avenidas de las aguas".

Dicha foto se localizó en el denominado Álbum de Granados, que es una colección de diez tomos de recortes de prensa sobre asuntos de importancia nacional, efectuada por Jaime Granados Chacón. Por una grata coincidencia, este cartaginés vivió en Turrialba, por lo que hay numerosos recortes sobre este cantón. Sin embargo, es de lamentar que él rara vez anotara la fuente y la fecha de los recortes compilados.

Es evidente la similitud del puente principal con el que fuera construido en el gobierno de Acosta (figura $8 \mathrm{~B}$ ) y con el del croquis recién mostrado (figura 9B). Sin embargo, es importante mencionar que la baranda del puente corto sí fue cambiada en algún momento, pues el original estaba compuesto por dos largos tubos, insertados en parales o pilares de metal (figura 8A). En cambio, el de la figura 10A y el del croquis -no mostrado aquí-, la baranda consistía en dos barras metálicas largas, atornilladas a seis parales insertados en la pieza que sirve de piso. Esto sugiere que -por ser de un material de menor calidad- el puente corto se oxidó y dañó, por lo que hubo que sustituirlo por uno mejor. Sí llama la atención que en el Archivo Nacional no haya información acerca de esta obra.

Se ignora en detalle lo acontecido con el citado puente a lo largo del tiempo, pero fue de gran utilidad por muchos años. Es de suponer que se le debieron hacer mejoras cada cierto tiempo, hasta que en algún momento quedó inservible. De él hoy persisten los bastiones de ambas riberas, más el que corona la gran roca que hay en medio del cauce y también ambas cerchas, bastante oxidadas y carcomidas por la intemperie. 

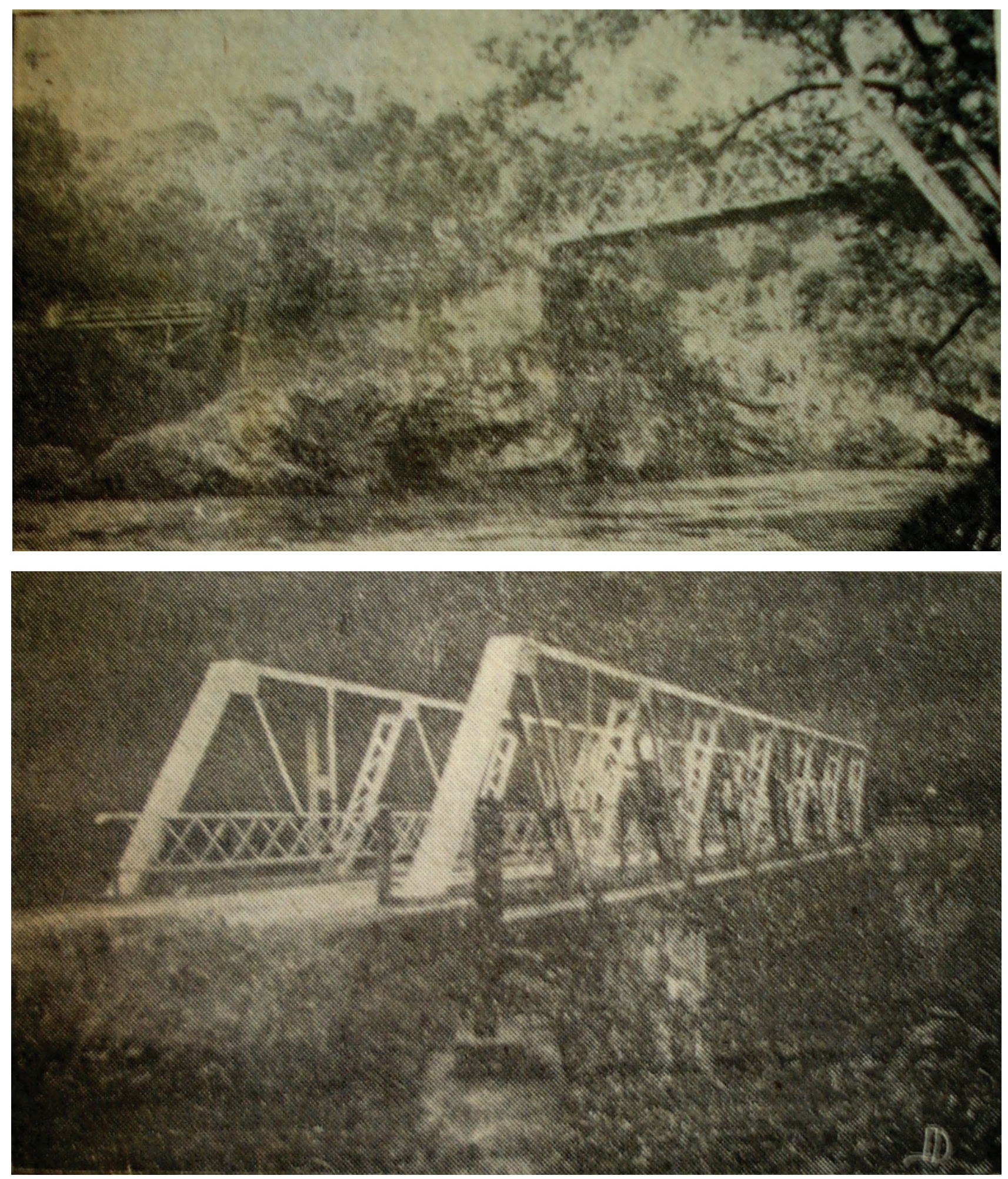

Figura 10. Panorámica de los dos puentes en Angostura (A) y una vista cercana del puente principal (B). En A, nótese la baranda del puente corto, a la izquierda. Fuente: Álbum de Granados 


\section{EL PUENTE ACTUAL}

Del actual puente, que fue construido durante el gobierno de Mario Echandi Jiménez (1958-1962), no hay más menciones en el Archivo Nacional y muy pocas -fragmentarias y casi irrelevantes- en las memorias de 1958-1959, 1959-1960 y 1960-1961 del Ministerio de Obras Públicas y Transportes (MOPT). En la de 1959-1960 hay una foto de los andamios de una pila en construcción. Por tanto, se ignora en qué momento surgió la iniciativa para su edificación y si esta provino de los habitantes de la zona, el gobierno o de ambos. No obstante, fue posible hallar los planos originales en el MOPT y en ellos se consigna que el puente fue diseñado entre marzo de 1959 y mayo de 1961. Esto revela que el proyecto se empezó a plasmar antes de que la administración Echandi Jiménez cumpliera un año de labores.

Eso sí, gracias a Salazar (1970) -quien era munícipe entonces- se sabe que la Municipalidad de Turrialba "colaboró hasta lo indecible en esta construcción, que estuvo a cargo del Ministerio de Transportes". Al respecto, hay muy poca información en las actas de dicha entidad. De hecho, hay una sola mención explícita a labores conjuntas con el entonces llamado Ministerio de Obras Públicas (MOP), referido al asfaltado de calles, el arreglo de caminos vecinales y la "construcción del puente sobre el Río Reventazón, denominado Angostura", para lo cual se hicieron erogaciones por $\$ 25.647,60$, incluyendo $\$ 8.647,60$ para el citado puente (Archivo Nacional de Costa Rica, 17 de enero de 1962). Asimismo, Salazar (1970) indica que "los planos fueron diseñados por los ingenieros Jorge Emilio Kepfer [Campos] y el turrialbeño Francisco Pereira [García]", quien laboraba para el MOP. Como una curiosidad, Kepfer es nieto del alemán Maximiliano Kepfer Köhler, de modo que -de una u otra manera- el ingenio alemán ha estado presente hasta hoy en varios de los puentes de Angostura.

Cabe acotar que los planos originales corresponden a 20 hojas, con todos los detalles técnicos para su construcción y en ellos consta que su principal artífice fue Kepfer, en tanto que Pereira se encargó de algunas partes. Los dibujos fueron trazados por una persona que firmaba con las iniciales A.S.R., que corresponden a Álvaro Sáenz R. La escala fue de 1:200 $(1 \mathrm{~cm}=2 \mathrm{~m})$.
En cuanto a sus características, el puente mide $103,26 \mathrm{~m}$ de longitud, 7,92 $\mathrm{m}$ de ancho y consta de cinco tramos o superestructuras de acero A36, simplemente apoyadas sobre un bastión en cada ribera, más cuatro pilas (pilares) en el lecho del río, con las dos pilas centrales sosteniendo una cercha. Sus respectivas longitudes corresponden a $14 \mathrm{~m}, 16,44 \mathrm{~m}$, $43,26 \mathrm{~m}, 16,44 \mathrm{~m}$ y $14 \mathrm{~m}$ (figura 11). El tramo central está conformado por la cercha de paso superior, de $42,67 \mathrm{~m}$ de longitud, en tanto que los otros cuatro son vigas laminadas de acero A36, con losa de concreto. La estructura se eleva $9 \mathrm{~m}$ sobre el nivel normal del agua y $4 \mathrm{~m}$ arriba del nivel máximo, según mediciones del ICE en $1955^{11}$.

A pesar de su importancia para el país, sobre este puente casi no hay información en la prensa de entonces. Fue cuando ya casi concluía la administración Echandi Jiménez que apareció una noticia en primera plana, intitulada San José y Siquirres quedarán conectados definitivamente por carretera durante el próximo verano, en la que se incluían los siguientes tres subtítulos o descriptores: "El puente sobre el río Reventazón en el lugar denominado La Angostura, se terminará de construir en enero próximo. / El MOP ha enviado un proyecto de ley a la Asamblea Legislativa para que se destine un millón y medio de colones más para la importante obra vial. / Quedará en esa forma debidamente terminado el primer tramo de la carretera a Limón" (Diario La Nación, 5 de setiembre de 1961).

En el interior del diario se reiteraba el título y se detaIlaba lo siguiente: "El señor Ministro de Obras Públicas, ingeniero Espíritu [Santo] Salas Salas, dijo para la prensa que el próximo verano quedará Siquirres conectado con la red nacional de carreteras. Agregó el ministro Salas que en enero de 1962 se terminará la construcción del puente sobre el río Reventazón en el lugar denominado La Angostura. Dicho puente tendrá un valor total de un millón de colones. Ahora el Ministerio de Obras Públicas ha presentado un proyecto de ley ante la Asamblea Legislativa para que se destine un millón y medio de colones para concluir la carretera a Siquirres, para dejar debidamente terminado el primer tramo de la carretera a Limón" (Diario La Nación, 5 de setiembre de 1961).

11 Explicación técnica de la Ing. María Ramírez (MOPT), con base en los citados planos. 
A juzgar por lo manifestado por Salas, destacado profesional que cumplió un papel clave durante la construcción de la célebre Carretera Interamericana, se aprovechó la instalación del puente para -de una vez- avanzar hacia el litoral Caribe, al menos hasta Siquirres. En cuanto al costo del puente, sería un poco más alto, como se verá pronto. Asimismo, de la citada noticia se colige que para inicios de setiembre ya la obra se había iniciado, lo cual tiene lógica, pues -como se indicó- los planos finales estuvieron confeccionados y aprobados en mayo de 1961.

No obstante, es posible que el proyecto avanzara lentamente, sobre todo por problemas económicos. En efecto, tal era la carencia de fondos, que en el ejemplar de La Nación de ese mismo día se informaba de las gestiones del MOP para que se le otorgaran los \$10.000.000 que había presupuestado para pagar salarios durante el segundo semestre de 1961. El monto le había sido recortado a $\$ 7.500 .000$ por el Poder Ejecutivo, pero los diputados lo incrementaron en un millón. Sin embargo, esos $\$ 8.500 .000$ eran insuficientes. De hecho, apenas dos días antes del anuncio acerca del nuevo puente en Angostura, Salas expresó que "la obra constructora del MOP está desarrollándose a toda celeridad, pese a las dificultades con la consecución de materiales y los dineros para pagar jornales, que con frecuencia se agotan" (Diario La Nación, 3 de setiembre de 1961). Por fortuna, dos semanas después los diputados asignaron al MOP un presupuesto extraordinario, por un monto de $\$ 3.634 .101$, para el período julio-setiembre (Diario La Nación, 19 de setiembre de 1961).

En realidad, tan seria era la situación del MOP que al pie de esa noticia se incluyó un gran recuadro con un anuncio oficial en el que se informaba "a todos sus trabajadores que el pago de sus jornales se iniciará el próximo jueves 21 de los corrientes". Garantizado este dinero, justamente ese día se publicó una amplia noticia que especificaba 20 obras del Departamento de Vialidad en todo el país, "las cuales se van a ejecutar inmediatamente, ya que en todos los casos las licitaciones han sido adjudicadas". Entre ellas no figuraba el puente en Angostura, pues es de suponer que ya había superado los respectivos trámites. Eso sí, se hace referencia a movimientos completos de tierra en los trayectos Turrialba-Siquirres y FlorenciaPuente Río Reventazón, al igual que el mejoramiento

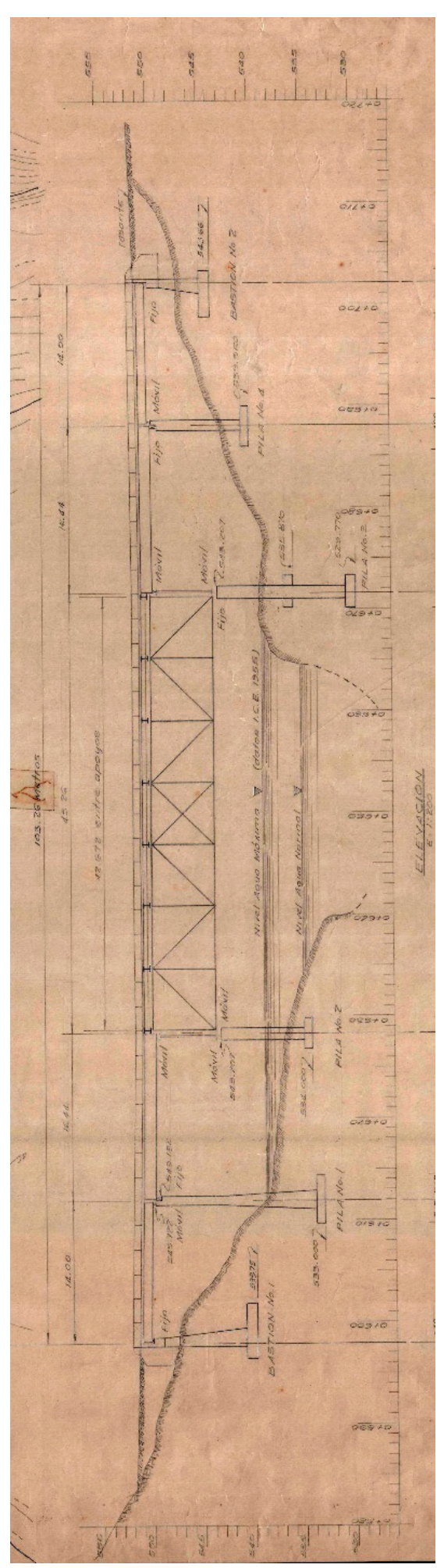

Figura 11. Diseño del puente actual. Fuente: Archivos MOPT 
y construcción del camino Guayabo-Peralta, en Turrialba (Diario La Nación, 21 de setiembre de 1961).

Es pertinente resaltar la fecunda obra vial liderada por el ministro Salas, quien a inicios de setiembre sin vanagloria expresaba que "a todo costarricense desapasionado le consta que la labor realizada por el Ministerio de Obras Públicas durante este gobierno ha sido mucha y se ha extendido por todos los lugares del país, incluso los más retirados". Y, tras referirse a nuevas escuelas, unidades sanitarias, carreteras, caminos y puentes, manifestaba que "en los pocos meses que faltan para que finalice su administración, [Echandi] no tendrá tiempo de inaugurar muchas obras que se comenzaron a construir cuando él inició su período, y que justamente en esta época se están terminando" (Diario La Nación, 3 de setiembre de 1961).

Se nota que era un profesional comprometido con el país, más allá de banderías políticas y que el gobierno lo supo respaldar. Tan es así que, en contraposición con la lamentable y arraigada costumbre politiquera de ejecutar obras que den réditos políticos de corto plazo, Salas emprendió un ambicioso Plan Vial a pocos meses de que la administración Echandi Jiménez concluyera, para el cual se buscó financiamiento en el extranjero. De hecho, un día después de la celebración de la independencia de Costa Rica, apareció una noticia en primera plana con el encabezado 300 millones para el Plan Vial y en la que se anunciaba la partida hacia Washington de una comitiva especial liderada por Salas. En el interior del diario figuraba una entrevista con Fernando Madrigal Antillón, presidente de la Asociación de Carreteras de Costa Rica, quien acompañaría a Salas como asesor. Él manifestaba que con los fondos esperados "se asegura el mantenimiento de las carreteras y caminos del país para los próximos cinco años, con una inversión que sobrepasa los 300 millones de colones, suma que nunca en la historia del país se ha logrado para este objetivo" (Diario La Nación, 16 de setiembre de 1961).

Pero -además- en ella se destacaba que "el próximo proyecto que desea impulsar la Asociación, y al que todos los costarricenses deben unirse, es la terminación de la carretera a Puerto Limón", después de lo cual argumentaba que "celebramos ayer la independencia, y en los días de la conquista los españoles tenían una vereda que comunicaba a la Zona Atlántica con la Meseta Central. Y es verdaderamente lamentable que en el año 1961, la provincia de Limón esté todavía desmembrada del sistema nacional de carreteras, lo que viene a ser inconcebible, por ser tan fértil, y que podrá convertirse en un verdadero emporio de riqueza para la economía nacional. Con la continuación de la carretera a Limón, que este gobierno lleva muy adelantada, Costa Rica contará en el futuro con una vía interoceánica, con las enormes ventajas que esto significa para la economía en general de nuestro país" (Diario La Nación, 16 de setiembre de 1961).

Para fortuna del país, dos semanas después se logró concretar el préstamo del Banco Mundial, de lo cual la prensa informó con el título Confirmado empréstito para Plan Vial; de ello se enteró el gobierno gracias a una comunicación "por la vía radiotelefónica" entre Salas y el presidente Echandi. Se consiguieron US\$11 000 000, a cancelarse el 50\% "a un interés muy conveniente", que no se menciona, y el otro $50 \%$ "sin intereses y a un plazo de cincuenta años" (Diario La Nación, 30 de setiembre de 1961).

Dos semanas después, en vísperas del retorno de Salas, la prensa detallaba cómo se invertirían los $\$ 120.950 .000$ adquiridos, que debían complementarse con los fondos propios y ordinarios del MOP. En la nota periodística se aclara que "este magno proyecto tiene dos etapas: una Plan Vial de Tres años, y el Plan total, que es de siete años" (Diario La Nación, 15 de octubre de 1961), y que comprende tres programas: construcción, mejoramiento y conservación (reconstrucción y mantenimiento). Es decir, se trataba de un proyecto de gran calado y largo aliento, concebido con la mira puesta en los verdaderos intereses del país y no en los de un partido político.

Para los fines del presente artículo, en dicha noticia figura como principal prioridad la carretera PavonesSiquirres-Limón, a la que se asignarían $\$ 7.000 .000$ y que no puede entenderse sin el puente en Angostura. Ahí se especifica que ese monto corresponde a 27 km, "en el segundo año de construcción de los tres años requeridos para completar los trabajos propuestos en esa ruta", lo cual es algo confuso. Después se anota que dicha carretera "necesita tres años para su ejecución, pero que no es posible iniciarla antes de tener listos los estudios preliminares, que no pueden 


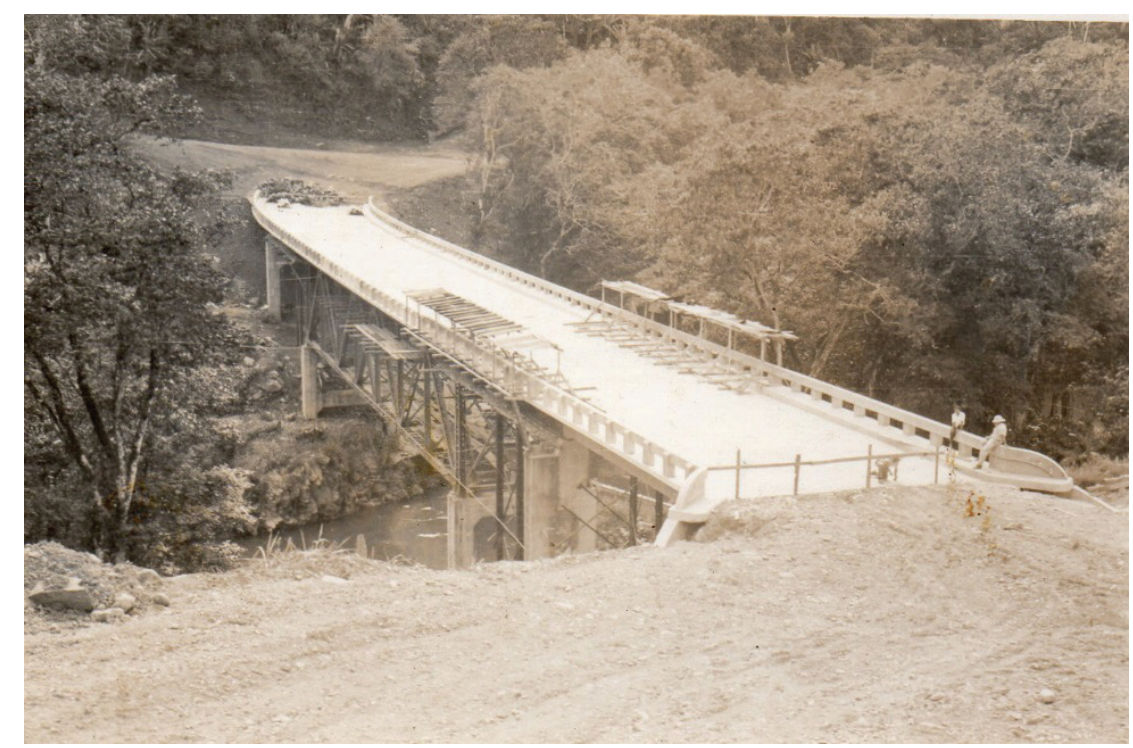

Figura 12. Puente actual, en la etapa final de su construcción. Fuente: Archivo Municipalidad de Turrialba

estar antes de un año". Asimismo, como una curiosidad y en relación con Turrialba, en dicho plan se presupuestaron $\$ 1.170 .000$ y $\$ 1.280 .000$ para el mejoramiento de las rutas Turrialba-Santa Cruz (21 km) y La Suiza-Moravia de Chirripó (32 km), respectivamente, así como $\$ 1.133 .000$ para la reconstrucción $(20$ km) de la ruta entre Cartago y Turrialba.

Para retornar a Angostura y su puente, quizás este estuvo culminado en enero, según lo previsto por el ministro Salas. Cabe destacar que en los actuales archivos de la Municipalidad de Turrialba existe una imagen -sin la fecha anotada- del puente casi concluido (figura 12), muy parecida a una que Salazar (1970) incluye en su libro. Sin embargo, es oportuno aclarar que la inauguración de obras públicas estuvo vedada del 10 de diciembre de 1961 al 4 de febrero de 1962, ya que el país vivía una campaña electoral y era inconveniente que estas actividades pudieran utilizarse con fines proselitistas. Por cierto, en dicha contienda resultó electo Francisco Orlich Bolmarcich, representante de la oposición, quien en el gobierno previo al de Echandi -presidido por José Figueres Ferrer (1953-1958)- había fungido como ministro de Obras Públicas.

Ahora bien, dado que la administración Echandi Jiménez efectuó tanta obra pública, es posible que se cumpliera el ya citado augurio del ministro Salas, al advertir que el calendario se haría corto para programar tantas inauguraciones. En efecto, poco después de concluida la contienda electoral, con el título Inauguración de obras la prensa anunció la intención del gobierno de establecer un programa de inauguraciones durante abril, el cual "comprende más de doscientas obras en todas las provincias del país", incluyendo "liceos, puentes, carreteras, [así como] edificios de todas magnitudes y para todas las funciones" (Diario La Nación, 18 de febrero de 1962). Obviamente, este era un tiempo insuficiente, además de que el gobierno saliente debía dedicar tiempo a otras actividades de igual o mayor relevancia para el país.

Tal era la importancia del puente en Angostura, que fue inaugurado nomás al comenzar ese mes, exactamente el domingo $1^{\circ}$ de abril de 1962.

Ese día apareció en la prensa un inmenso anuncio que ocupó las dos planas centrales del principal periódico del país, que con grandes letras decía: "El Gobierno de la República / por medio del Ministerio de Obras Públicas / invita a la entrega de obras materiales en el cantón de Turrialba / Domingo $1^{\circ}$ de abril a partir de las 9 horas". Lo ilustran diez fotos: dos del puente en Angostura, una del puente en La Margot, tres del Colegio Clodomiro Picado, una de las respectivas escuelas de Florencia y Javillos, una del Gimnasio Municipal y una del Estadio Municipal (Diario La Nación, $1^{\circ}$ de abril de 1962). De las fotos referidas a nuestro puente de interés, una corresponde a una panorámica de su estructura, en tanto que la otra es una vista lateral de su cercha inferior. Deba- 
jo de esta última, una leyenda reza así: "Puente sobre el río Reventazón, paso "La Angostura". Uno de los más grandes de Costa Rica (103 metros). Primer paso importante en la construcción de la carretera a Limón. Un costo del orden de ф1.200.000.00".

En cuanto al costo de la obra, nótese que esta cantidad es superior a la previamente indicada por el propio ministro del ramo, lo cual quizá obedeció a erogaciones imprevistos. Al respecto, Salazar (1970) especifica un monto de $\$ 1.288 .005,71$. Pero a continuación incluye una acotación que puede inducir a confusión, en el sentido de sugerir que fue la Municipalidad de Turrialba la que hizo ese aporte. No obstante, esto es impensable, a juzgar por los bajos montos que usualmente manejaba esta entidad, según se colige de la revisión de las actas municipales. Como una curiosidad, las instalaciones del Colegio Clodomiro Picado, incluyendo su gimnasio, también costaron $\$ 1.200 .000$.

Para retornar a la inauguración del puente en Angostura, Ilama la atención que en la prensa no aparecieran más noticias de tan importante evento histórico -en marcado contraste con el puente erigido en el gobierno de Julio Acosta-, lo cual se podría explicar porque quizás se le visualizaba como apenas un componente o una parte de la futura carretera a $\mathrm{Li}$ món, como el propio gobierno lo consignó en su invitación abierta al público. Sin embargo, en Turrialba sí se le dio la debida relevancia a esta y otras obras de gran importancia para el cantón. Al respecto, unas dos semanas antes, siguiendo instrucciones del ministro Salas, el ingeniero residente del MOP en el cantón -cuyo nombre no se menciona- contactó al Concejo Municipal, presidido por Macario Fuentes Martínez, para informarle acerca de las intenciones del gobierno de inaugurar varias obras ese mismo día, con la asistencia del presidente Echandi (Archivo Nacional de Costa Rica, 14 de marzo de 1962).

Por tanto, se encargó a la Comisión Municipal de Educación (Omar Salazar Obando, Arnoldo Núñez Vetrano, Lolita Arce de Quesada, Marco Tulio Castro Carrillo y José Ángel Meneses Garita) la elaboración de un programa de actividades para tan fastuosa ocasión. A ella se sumarían el regidor Rogelio Carazo Paredes, José María Castillo Pineda (ejecutivo municipal) y el secretario municipal (¿Carlos Solano Salazar?), más los profesores Edwin Murillo Cartín y Her- nán Brenes Quesada. Para dicho evento se preparó un presupuesto de $\$ 3.000$, tomado de varias partidas municipales, que fue avalado por la Contraloría General de la República; con él se pagó la impresión de las invitaciones correspondientes, un refrigerio para los estudiantes y el público, más un almuerzo para la comitiva presidencial.

Se ignora si el programa se cumplió exactamente como lo diseñó la citada comisión, pues no se cuenta con información posterior a los actos de ese día. En todo caso, las actividades se iniciarían a las nueve de la mañana, con la inauguración y bendición del puente "La Margot" -ahora conocido como puente de Las Monjas, por la cercanía de la Escuela de Sióny el Gimnasio Municipal -hoy parte del edificio del Colegio Nocturno Enrique Menzel-, así como obras relacionadas con el mejoramiento de la cañería y el asfaltado de calles. Dos horas después se haría lo propio con el Instituto Superior de Educación, es decir, el Colegio Clodomiro Picado. A partir de las tres y media de la tarde, y por lapsos de media hora, se procedería con la escuela de Florencia, el puente de Angostura y la escuela de Javillos, en esa secuencia (Archivo Nacional de Costa Rica, 21 de marzo de 1962). Llama la atención que no se mencione el Estadio Municipal, que figuraba en el anuncio del gobierno, aunque en la foto incluida en este se ve una especie de vivero, quizás para la gramilla que se estaba estableciendo.

La bendición de las obras estuvo a cargo de Alfonso Hoefer Hombach, obispo de la diócesis de Limón, en tanto que el Himno Nacional fue entonado por la Banda Municipal. Por cierto, esta estaba dirigida por el maestro Elpidio Salas Miranda, quien pocos años antes había sustituido a su padre Donato Salas Cantillano, que había ejercido ese puesto por unos 30 años. Asimismo, de las escuelas locales, una delegación de la de Sión estuvo en el puente "La Margot" y una de la Mariano Cortés en el Gimnasio Municipal, en tanto que diez alumnos de cada una de dichas escuelas, más una cantidad equivalente de las escuelas centrales y del colegio nocturno se congregaron en el Instituto Superior de Educación, para sumarse a los 500 estudiantes de este, conformando así una nutrida concurrencia.

Lamentablemente, la inauguración del puente de Angostura fue eclipsada por varios factores. En pri- 
mer lugar, fue en dicho instituto donde tuvo lugar el acto principal de ese día. Iniciado con las notas del Himno Nacional y seguido por la bendición de tan amplias y bellas instalaciones, era el sitio ideal para escuchar las alocuciones de rigor, incluyendo las de varios ministros y del presidente Echandi. En segundo lugar, después de este acto hubo una prolongada recepción para el presidente y su comitiva en casa del regidor Carazo, y saciadas con holgura el hambre y la sed, más el cansancio acumulado, pareciera que el ánimo daba tan solo para cumplir con los actos protocolarios programados. En tercer lugar, como había que alejarse un poco de la ciudad y el tiempo apremiaba, dado que se disponía de apenas hora y media para desplazarse hasta Florencia, Angostura y Javillos, y efectuar las respectivas ceremonias, quizás no muchas personas -ni la Banda Municipal-pudieron sumarse a la comitiva presidencial hasta dichas localidades.

En síntesis, pareciera que -en una ceremonia sumaria- todo cuanto recibió el magnífico puente fue el rociado con agua bendita de manos del obispo Hoefer, más quizás unas breves palabras del presidente, en medio de los aplausos de una raquítica concurrencia. No hubo escolares, colegiales ni solemnes discursos ni tampoco palpitaron ahí, vibrantes y conmovedoras, las augustas notas del Himno Nacional, como ocurriera cuando -muchos años antes- los presidentes Jiménez y Acosta se apersonaron a Angostura para sus respectivas inauguraciones.

En todo caso y a pesar de tal deuda -debido a su significado a lo largo de la historia-, desde entonces este hermoso y sólido puente (figura 13A-B) ha permanecido incólume, haciendo posible el incesante tránsito rumbo a La Suiza y Moravia de Chirripó hacia la derecha, así como también hacia todos los poblados y caseríos surgidos a lo largo de la ruta nacional 10, que termina en Siquirres y que -continuada por la ruta 32- culmina en Puerto Limón.

\section{EPÍLOGO}

Como se ha mostrado en este artículo, fueron los mandatarios Braulio Carrillo y Juan Rafael Mora los que más se empeñaron en construir un camino que uniera el Valle Central con Puerto Limón. Sin embargo, sus anhelos toparon con numerosos obstáculos, tanto políticos y económicos como físicos, entre los que sobresalió el río Reventazón. Por fortuna, este pudo ser soslayado gracias a los puentes erigidos en Angostura en los gobiernos de Jesús Jiménez, Julio Acosta y Mario Echandi, aunque no se contó con una carretera hasta Puerto Limón.

No obstante, sí es claro que recién instalado el actual puente, de manera relativamente rápida se pudo avanzar al menos hasta Siquirres. De ello da fe Salazar (1970), al narrar que "la carretera PavonesSiquirres es una arteria de incalculables beneficios para nuestro cantón. Tierras inhóspitas por boscosas e infectas, hoy haánse [sic] convertido en glebas fertilísimas, cuyos frutos salen al mercado por medio de esa oportuna ruta. El trayecto es de una longitud de 60 kilómetros aproximadamente, y conduce al viajero por lugares rebosantes de pinturas naturales, en donde se pueden distinguir enormes extensiones de terreno virgen que piden llegue hasta ellos la planta del hombre laborioso. Esa vía nacional ofrece excelente amplitud, y en ella se están poniendo en juego las técnicas más modernas de construcción de carreteras". Completar la ruta hasta Puerto Limón demoró muchos años y, tras varios intentos parciales, no sería inaugurada sino muchos años después, en la administración de Daniel Oduber Quirós (1974-1978).

Para concluir, y a manera de recapitulación, el actual puente fue construido cuando la tecnología ya permitía instalar una extensa estructura en un sector amplio del cauce, lo cual era inimaginable en otras épocas. Por tanto, al analizar lo acontecido, es evidente que para entonces ya no se necesitaba la estrechez o angostura de mediados del siglo XIX, ni tampoco la gran roca que se yergue en el centro del cauce. Es decir, si en aquella época ya se hubiera dispuesto de la tecnología adecuada, el puente se podría haber construido en un sector menos escabroso de la cuenca del río Reventazón, algo lejos del sitio actual, quizás en las cercanías de Tucurrique, de modo que la actual carretera no existiría. Por ello, fue gracias al descubrimiento de una angostura apta por parte de Antolín Quesada, así como la construcción del primer puente -levantado por Espinach y ayudantesque se definió el trazo del actual camino por esos parajes, al igual que la existencia misma de Turrialba como un pueblo prominente y próspero. 

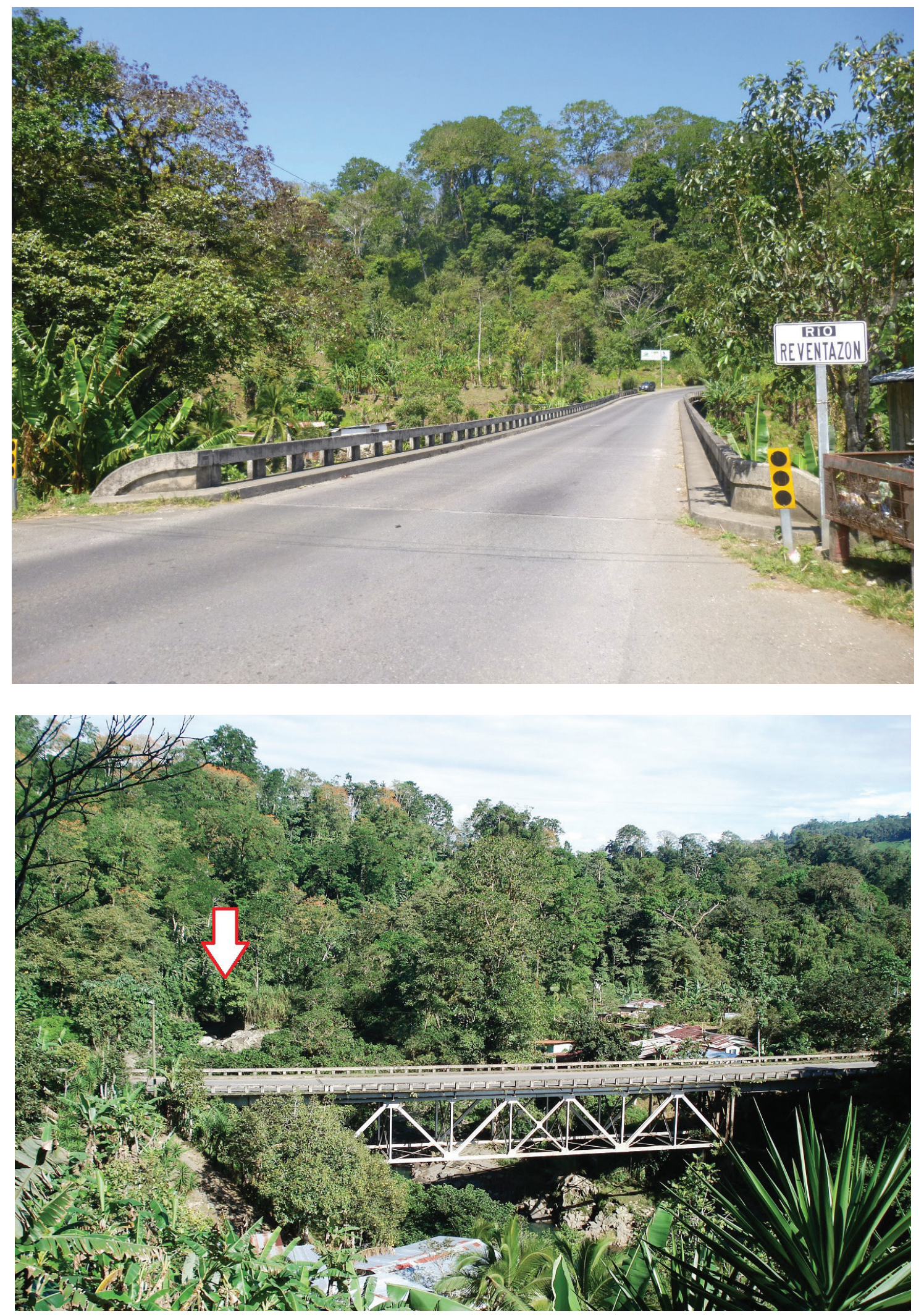

Figura 13. Vista del puente (A), así como de la cercha inferior (B). En 13B, la flecha indica la ubicación del antiguo puente de metal. Fuente: Luko Hilje. 


\section{AGRADECIMIENTOS}

Este artículo está dedicado a la memoria del ingeniero alemán Francisco Kurtze, constructor lo mismo de puentes que de sueños. Agradecemos a quienes hicieron posible localizar la información esencial, como Vinicio Méndez Mora y Jafeth Campos Ramírez (Archivo Nacional), Laura Rodríguez Amador y Rosa Elena León Sorio (Biblioteca Nacional) y Ana Lorena Abarca Anchía, María Ramírez González, Gabriela Muñoz Peralta y Edgar Córdoba Álvarez (MOPT). También, la útil información o imágenes aportadas por algunos de ellos y por Walter Velásquez Madriz (Municipalidad de Turrialba), Antonio Vargas Campos (Archivos del Museo Histórico Cultural Juan Santamaría, MHCJS), Julio Ernesto Revollo Acosta, Silvia Meléndez Dobles, Juan Manuel Castro Alfaro, Jorge Emilio Kepfer Campos, Beatriz Salas Feyth, Rodolfo Silva Vargas, Juan Carlos Solórzano Fonseca, Irene Reinhold, Quírico Jiménez Madrigal, Mariela Tortós González y Walter Antillón Montealegre.

\section{BIBLIOGRAFÍA}

Anónimo. (1953). Costa Rica Railway Company Ltd. and Northern Railway Company. San José, Costa Rica.

Archivo Nacional de Costa Rica. (29 de setiembre de 1846). Congreso 5659.

Archivo Nacional de Costa Rica. (1850). Fomento 1689.

Archivo Nacional de Costa Rica. (1851). Congreso 11850.

Archivo Nacional de Costa Rica. (25 de mayo de 1851). Fomento 1673 y 1681, sesión 17.

Archivo Nacional de Costa Rica. $\left(1^{\circ}\right.$ de junio de 1851). Fomento 1673 y 1681, sesión 18.

Archivo Nacional de Costa Rica. (8 de junio de 1851). Fomento 1673 y 1681, sesión 19.

Archivo Nacional de Costa Rica. (15 de junio de 1851). Fomento 1673 y 1681, sesión 20.

Archivo Nacional de Costa Rica. (28 de setiembre de 1851). Fomento 1673 y 1681, sesión 32.

Archivo Nacional de Costa Rica. (12 de octubre de 1851). Fomento 1673 y 1681, sesión 33.
Archivo Nacional de Costa Rica. (15 de octubre de 1851). Fomento 4467 , f. 5-5v.

Archivo Nacional de Costa Rica. (7 de diciembre de 1851). Fomento 1673 y 1681, sesión 37.

Archivo Nacional de Costa Rica. (2 de febrero de 1852). Fomento 1673, sesión 4.

Archivo Nacional de Costa Rica. (4 de febrero de 1852). Fomento 4467, carta No. 2.

Archivo Nacional de Costa Rica. (30 de mayo de 1852). Fomento 1673, sesión 20.

Archivo Nacional de Costa Rica. (26 de setiembre de 1852). Fomento 4467, sesión No. 13, f. 12v-13.

Archivo Nacional de Costa Rica. (1864). Planos 7300-18, No. 34.

Archivo Nacional de Costa Rica. (1866). Fomento 765, f. 1-22.

Archivo Nacional de Costa Rica. (1890). Fomento 1240.

Archivo Nacional de Costa Rica. (1915). Asamblea Legislativa 11006.

Archivo Nacional de Costa Rica. (1920-1929). Fomento 10447.

Archivo Nacional de Costa Rica. (20 de marzo de 1921). Municipalidad de Turrialba 18683, pp. 64-65.

Archivo Nacional de Costa Rica. (4 de noviembre de 1921). Fomento 11747.

Archivo Nacional de Costa Rica. (1922). Asamblea Legislativa 12605.

Archivo Nacional de Costa Rica. (22 de febrero de 1922). Municipalidad de Turrialba 18683, pp. 138-139.

Archivo Nacional de Costa Rica. (8 de marzo de 1922). Municipalidad de Turrialba 18683, pp. 144-145.

Archivo Nacional de Costa Rica. (24 de mayo de 1922). Municipalidad de Turrialba 18683, pp. 175-176.

Archivo Nacional de Costa Rica. (9 de agosto de 1922). Municipalidad de Turrialba 18683, pp. 208. 
Archivo Nacional de Costa Rica. (23 de agosto de 1922). Municipalidad de Turrialba 18683, pp. 210-211 y Gobernación 34852.

Archivo Nacional de Costa Rica. (13 de setiembre de 1922). Municipalidad de Turrialba 18683, pp. 214-215 y Gobernación (1922) 34852.

Archivo Nacional de Costa Rica. (16 de noviembre de 1922). Municipalidad de Turrialba 18683, p. 234.

Archivo Nacional de Costa Rica. (27 de diciembre de 1922). Municipalidad de Turrialba 18683, p. 252.

Archivo Nacional de Costa Rica. (14 de febrero de 1923). Municipalidad de Turrialba 18683, p. 266.

Archivo Nacional de Costa Rica. (22 de febrero de 1923). Municipalidad de Turrialba 18683, pp. 267-268.

Archivo Nacional de Costa Rica. (23 de mayo de 1923). Municipalidad de Turrialba 18684, p. 3.

Archivo Nacional de Costa Rica. (13 de enero de 1926). Municipalidad de Turrialba 18685, p. 42.

Archivo Nacional de Costa Rica. (20 de enero de 1926). Municipalidad de Turrialba 18685, p. 45.

Archivo Nacional de Costa Rica. (1942). Juzgado Contencioso Administrativo 2526.

Archivo Nacional de Costa Rica. (10 de enero de 1943). Municipalidad de Turrialba 18694, p. 12.

Archivo Nacional de Costa Rica. (28 de noviembre de 1946). Municipalidad de Turrialba 18694, pp. 196-209.

Archivo Nacional de Costa Rica. (2 de marzo de 1949). Municipalidad de Turrialba 18695, p. 127.

Archivo Nacional de Costa Rica. (17 de enero de 1962). Municipalidad de Turrialba 18707, pp. 240-241.

Archivo Nacional de Costa Rica. (14 de marzo de 1962). Municipalidad de Turrialba 18707, p. 324.

Archivo Nacional de Costa Rica. (21 de marzo de 1962). Municipalidad de Turrialba 18707, pp. 346-348.
Benzoni, G. (1989). Historia del nuevo mundo. (Trad. Manuel Carrera Díaz). Madrid: Alianza Editorial.

Calvert, A.S. y Calvert, P.P. (1917). A year of Costa Rican natural history. New York: The Macmillan Co.

Carrandi y Menan, F.A. (s.f.). Viaje del gobernador Carrandi Menan al Valle de Matina. Año 1738. San José, Costa Rica: Imprenta Nacional.

Cooper, E. (1896). Informe sobre el camino a Matina y la costa del norte ( $2^{\mathrm{a}}$ ed.). San José, Costa Rica: Tipografía Nacional.

Diario del Comercio. (27 de mayo de 1923). No. 810, p. 1.

Diario del Comercio. (31 de mayo de 1923). No. 813, p. 8.

Diario del Comercio. (5 de junio de 1923). No. 816, p. 1.

Diario La Nación. (3 de setiembre de 1961). p. 79.

Diario La Nación. (5 de setiembre de 1961). pp. 1 y 27.

Diario La Nación. (16 de setiembre de 1961). p. 4.

Diario La Nación. (19 de setiembre de 1961). p. 14.

Diario La Nación. (21 de setiembre de 1961). p. 8.

Diario La Nación. (30 de setiembre de 1961). p. 47.

Diario La Nación. (15 de octubre de 1961). p. 15.

Diario La Nación. (18 de febrero de 1962). p. 18.

Diario La Nación. (1 de abril de 1962). pp. 40-41.

Hilje, L. (2008). El valle de Orosi, explorado por Alexander von Frantzius. Revista Comunicación, 17(1), 80-103.

Hilje, L. (2013). Trópico agreste; la huella de los naturalistas alemanes en la Costa Rica del siglo XIX. Cartago, Costa Rica: Editorial Tecnológica de Costa Rica.

Hilje, L. (en prensa). La bandera prusiana ondeó en Angostura. Instituto Costarricense de Electricidad (ICE). Proyecto Hidroeléctrico Reventazón. San José, Costa Rica.

Ibarra, E. (1985). Al encuentro de Turrialba la grande y Turrialba la chica: pueblos juntos del siglo XVI (1569-1600) [Edición Especial]. Revista de Ciencias Sociales, 2, 77-85. 
Ibarra, E. (1999). Las manchas del jaguar: huellas indigenas en la historia de Costa Rica, Valle Central, siglos XVI-XX. San José, Costa Rica: Editorial de la Universidad de Costa Rica.

Ibarra, E. (2002). Las sociedades cacicales de Costa Rica (siglo XVI). Colección Historia de Costa Rica. San José, Costa Rica: Editorial de la Universidad de Costa Rica.

Kuntze, O. (2001). Alrededor del mundo (Diario escrito en Costa Rica). En M.A. Quesada Pacheco (Ed.), Entre silladas y rejoyas; viajeros por Costa Rica de 1850 a 1950 (pp. 271-299). Cartago, Costa Rica: Editorial Tecnológica de Costa Rica.

La Gaceta. (13 de julio de 1850). No. 85, p. 553.

La Gaceta. (27 de julio de 1850). No. 87, pp. 562563.

La Gaceta (14 de febrero de 1852). No. 166, p. 2

La Gaceta. (19 de junio de 1852). No. 189, p. 1.

La Gaceta. (8 de abril de 1865). No. 312, p. 4.

La Tribuna. (3 de junio de 1923). No. 953, p. 5.

La Tribuna. (5 de junio de 1923). No. 954, p. 5.

Marr, W. (2002). Viajes por Centroamérica. En R. Fernández Guardia (ed.), Costa Rica en el siglo XIX; relatos de viajeros (pp. 95-210). San José, Costa Rica: EUNED.

Meagher, T.F. (2002). Vacaciones en Costa Rica. En R. Fernández Guardia (ed.), Costa Rica en el siglo XIX; relatos de viajeros (pp. 271-369). San José, Costa Rica: EUNED.

Molina Montes de Oca, C.M. (2005). Y las mulas no durmieron...; los arrieros en Costa Rica, siglos XVI al XIX. San José, Costa Rica: EUNED.

Monge, C. (1976). Historia de Costa Rica (14 ed.). San José, Costa Rica: Trejos Hermanos.

Obregón, C. (1989). Carrillo: una época y un hombre (1835-1842). San José, Costa Rica: Editorial Costa Rica.

Obregón, C. (2002). Nuestros gobernantes: verdades del pasado para comprender el futuro ( $2^{\mathrm{a}} \mathrm{ed}$.). San José, Costa Rica: Editorial de la Universidad de Costa Rica.

Polakowsky, H. (2014). Algunas noticias sobre la parte oriental del estado libre de Costa Rica. En
E. Zeledón (ed.), Viajes por Costa Rica. Tomo II. San José, Costa Rica: EUNED.

Salazar, O. (1970). Monografía de Turrialba. Turrialba, Costa Rica: Municipalidad de Turrialba.

Sociedad Itineraria del Norte (SIN). (1852). Memoria y Cuenta General que la Junta Directora de la Sociedad Itineraria del Norte presenta a ésta, de sus operaciones en el año de 1851. San José, Costa Rica: Imprenta de La Paz.

Tristán, J.F. (1922). Karl von Seebach y sus estudios sobre Costa Rica. Publicaciones Liceo de Costa Rica, No. 9. San José, Costa Rica: Imprenta Lehmann.

Valerio, J. (1953). Turrialba, su desarrollo histórico. San José, Costa Rica: Editorial Tormo.

Vargas, J.C. (Ed.). (2008). Tropical travel; the representation of Central America in the 19th century. San José: Editorial de la Universidad de Costa Rica. 